\title{
Modeling debris flow initiation and run-out in recently burned areas using data-driven methods
}

\author{
Raquel Melo ${ }^{1}$ (D) José Luís Zêzere ${ }^{1}$
}

Received: 1 June 2016/Accepted: 11 May 2017/Published online: 19 May 2017

(C) Springer Science+Business Media Dordrecht 2017

\begin{abstract}
In the framework of the landslide susceptibility assessment, the maps produced should include not only the landslide initiation areas, but also those areas potentially affected by the traveling mobilized material. To achieve this purpose, the susceptibility analysis must be separated in two distinct components: (1) The first one, which is also the most discussed in the literature, deals with the susceptibility to failure, and (2) the second component refers to the run-out modeling using the initiation areas as an input. Therefore, in this research we present a debris flow susceptibility assessment in a recently burned area in a mountain zone in central Portugal. The modeling of debris flow initiation areas is performed using two statistical methods: a bivariate (information value) and a multivariate (logistic regression). The independent validation of the results generated areas under the receiver operating characteristic curves between 0.91 and 0.98 . The slope angle, plan curvature, soil thickness and lithology proved to be the most relevant predisposing factors for the debris flow initiation in recently burned areas. The run-out is simulated by applying two different methods: the empirical model Flow Path Assessment of Gravitational Hazards at a Regional Scale (Flow-R) and the hydrological algorithm D-infinity downslope influence (DI). The run-out modeling of the 36 initiation areas included in the debris flow inventory delivered a true positive rate of $83.5 \%$ for Flow-R and $80.5 \%$ for DI, reflecting a good performance of both models. Finally, the susceptibility map for the entire basin including both the initiation and the run-out areas in a scenario of a recent wildfire was produced by combining the four models mentioned above.
\end{abstract}

Keywords Debris flow $\cdot$ Initiation areas $\cdot$ Run-out $\cdot$ Data-driven methods $\cdot$ Burned areas

Raquel Melo

raquel.melo@campus.ul.pt

1 Centre for Geographical Studies, Institute of Geography and Spatial Planning, Universidade de Lisboa, Edifício IGOT, Rua Branca Edmée Marques, 1600-276 Lisbon, Portugal 


\section{Introduction}

Debris flows are one of the most hazardous types of landslides in mountain regions, not only for their high velocities, impact forces and long run-out distances, but also for the difficulty in establishing a temporal prediction (Jakob and Hungr 2005). When debris flows occur in densely populated areas, they are often responsible for loss of lives and damage to infrastructures. Consequently, the socioeconomic impact can be truly dramatic.

The development of an integrated analysis combining the assessment of landslide initiation and run-out areas has been suggested by many authors as an appropriate solution to predict landslide susceptibility (e.g., Dai and Lee 2002; Dai et al. 2002; Corominas et al. 2003; Hürlimann et al. 2006; Van Westen et al. 2006; Guinau et al. 2007; Clerici et al. 2010; Dahl et al. 2010; Greiving et al. 2014). Therefore, susceptibility maps should include the landslide initiation areas as well as those areas potentially affected by the traveling mobilized material. To achieve this purpose, the susceptibility analysis must be separated in two distinct components (Greiving et al. 2014): (1) The first one, which is also the most discussed in the literature, deals with the susceptibility to failure, and (2) the second component refers to the run-out modeling using the initiation areas as an input.

The susceptibility mapping of potential failures reflects the spatial probability for the occurrence of future landslides and can be prepared using qualitative (heuristic) or quantitative (statistical and deterministic) methods (e.g., Carrara et al. 1995; Soeters and Van Westen 1996; Guzzetti et al. 1999, 2006; Dai et al. 2002; Van Westen et al. 2006, 2013; Hervás and Bobrowsky 2009; Clerici et al. 2010; Vergari et al. 2011). The heuristic methods are knowledge driven and can be subdivided into direct (geomorphological analysis/direct mapping) and indirect (indexing). The latter is based on the assignment of a specific weight to each variable responsible for the geomorphological instability. Therefore, the landslide mapping is based on subjective decisions, which is the major drawback of this method (e.g., Guzzetti et al. 1999; Van Westen et al. 2013). In the last 20 years, technological advances and geographic information systems (GIS) allowed the development of quantitative methods to assess landslide susceptibility (e.g., Van Westen et al. 2006; Bai et al. 2010b, 2011). Statistical models (bivariate and multivariate) have become the most frequently used (Hervás et al. 2013). They allow the quantification of the specific weight of each variable on the slope instability and the validation of the results through success and prediction rates (e.g., Chung and Fabbri 2003; Zêzere et al. 2004; Guillard and Zêzere 2012) or receiver operating characteristic (ROC) curves (e.g., Beguería 2006; Gorsevski et al. 2006; Van den Eeckhaut et al. 2009; Frattini et al. 2010). The deterministic (or physically based) approach requires the knowledge of geotechnical and hydrological parameters of the soil. The uncertainty inherent to these data as well as to the depth and geometry of the surfaces of rupture has motivated the choice of simple methods such as the infinite slope model to calculate the safety factor (e.g., Montgomery and Dietrich 1994; Van Westen and Terlien 1996; Delmonaco et al. 2003; Ray and De Smedt 2009).

Once the potential terrain failures are identified, the run-out behavior is analyzed in order to define the flow path and the areas affected by the deposition of the mobilized material. Run-out parameters include the maximum distance traveled, flow velocity, thickness and distribution of the deposit, and the impact force against obstacles (Hungr 1995). The run-out can be analyzed by using simple flow direction algorithms (e.g., Guinau et al. 2007; Kritikos 2013), empirical-statistical approaches (e.g., Benda and Cundy 1990; Corominas 1996; Rickenmann 1999; Fannin and Wise 2001; Scheidl and Rickenmann 
2010), analytical methods (e.g., Hürlimann et al. 2007) and dynamic methods (e.g., O'Brien et al. 1993; Iovine et al. 2003; D'Ambrosio et al. 2003; Hungr and McDougall 2009; Beguería et al. 2009; Christen et al. 2010; Quan Luna et al. 2012, 2016; Avolio et al. 2013). The flow direction analysis relies on the assumption that debris flows triggered by intense rainfall tend to converge with the drainage network and travel long distances following the steepest slope (Guinau et al. 2007). In this case, simple hydrological algorithms can be used to calculate the flow direction in each cell of the digital elevation model (DEM) (Hürlimann et al. 2007). Frequently, the assessment of flow velocities and traveled distances using empirical methods is based on field surveying and on the relationship analysis between the debris volume, the distance traveled and the morphology of the path (Hungr et al. 2005). However, this type of approach does not take into consideration the physical processes or mechanisms controlling the mass movement and deposition (Fannin and Wise 2001). The analytical method, also referred to as mass point model (Hürlimann et al. 2007; Mergili et al. 2012b), incorporates a simple flow resistance law to estimate the flow velocity along a pre-defined path. A significant drawback of this approach is related to the fact that the debris flow mass is defined by a single point (Mergili et al. 2012a, b). Consequently, instead of considering the entire moving mass only the displacement of the gravity point can be calculated (Legros 2002). Such limitation may introduce significant errors in the assessment of the maximum run-out, since the distance between the gravity point and the distal limit of the debris flow deposit can be considerable. The dynamic simulation of the run-out is numerically solved through deterministic models based on fluid mechanics. The debris motion relies on the application of conservation laws of mass, momentum and energy, and the material behavior is defined by its rheological properties (Dai et al. 2002; Quan Luna et al. 2012, 2016). This type of models allows the estimation of flow velocities, thickness of the deposits, impact force against obstacles and the total extent of the displaced mass. However, the physically based approaches are generally applied at a local level, serving as a support to the development of warning systems and structural mitigation measures (Quan Luna et al. 2014).

The run-out behavior is determined by several factors, including the topography, soil properties, land use, debris volume and water content (Guinau et al. 2007). Regarding the complexity and spatial variability of some of these parameters, the run-out modeling is rarely performed at the regional scale (Corominas et al. 2014). Consequently, the medium and regional scale analysis is generally supported by empirical models, since they require limited data. Nevertheless, they provide a preliminary identification of potentially affected areas which may be subject of more detailed studies afterward (Kappes et al. 2011).

The generation of debris flows in recently burned areas has been the subject of several studies along the last decades (e.g., Wohl and Pearthree 1991; Cannon et al. 1998; Cannon and Reneau 2000; Cannon 2001; Cannon et al. 2001a, b; Cannon and Gartner 2005; Cannon et al. 2008, 2010, 2011; Riley 2013; Staley et al. 2013, 2014). In burned areas, debris flows can be initiated by two distinct processes or even by the combination of both (e.g., Cannon 2001; Cannon et al. 2001a, b; Cannon and Gartner 2005): infiltration-triggered soil slips and surface runoff erosion with entrainment of loose material. Although the latter is frequently referred as the dominant process (Cannon et al. 2001a; Cannon and Gartner 2005; Cannon et al. 2008), both can occur within a few years after the fire took place (Cannon et al. 2001b). The fire effect on the hydrological response of a basin includes the consumption of vegetation, ash deposition, changes in physical properties of soils and rocks and the presence of water-repellent soils (Cannon and Gartner 2005; Cannon et al. 2010; Parise and Cannon 2012). Such characteristics lead to a decrease in the 
infiltration rate and, consequently, to the increase in the surface runoff (Cannon 2001; Cannon and Gartner 2005; Cannon et al. 2010).

In this research, we present a debris flow susceptibility assessment in a recently burned area in a mountain zone in central Portugal. The modeling of debris flow initiation is performed using two statistical methods: a bivariate (information value) and a multivariate (logistic regression). The run-out is simulated by applying two different methods: the empirical model Flow Path Assessment of Gravitational Hazards at a Regional Scale (Flow-R) and the hydrological algorithm D-infinity downslope influence (DI). The main objective of this work is to construct a final debris flow susceptibility map for the entire basin including both the initiation and the run-out areas in a scenario of a recent wildfire. Finally, this work also intends to achieve a combination of low-cost methodology with limited input data that allows a good performance of the susceptibility assessment and can be easily applied to other study regions.

\section{Study area}

The debris flow susceptibility was assessed in the Zêzere valley, Serra da Estrela, Portugal (Fig. 1). Serra da Estrela $\left(40^{\circ} 20^{\prime} \mathrm{N}, 7^{\circ} 35^{\prime} \mathrm{W}\right)$ is the highest mountain massif in Portugal mainland (1993 $\mathrm{m}$ a.s.l. in Torre plateau). The massif develops in a SW-NE direction and presents an elongated shape ca. $45 \mathrm{~km}$ long and $20 \mathrm{~km}$ wide. The relief is characterized by
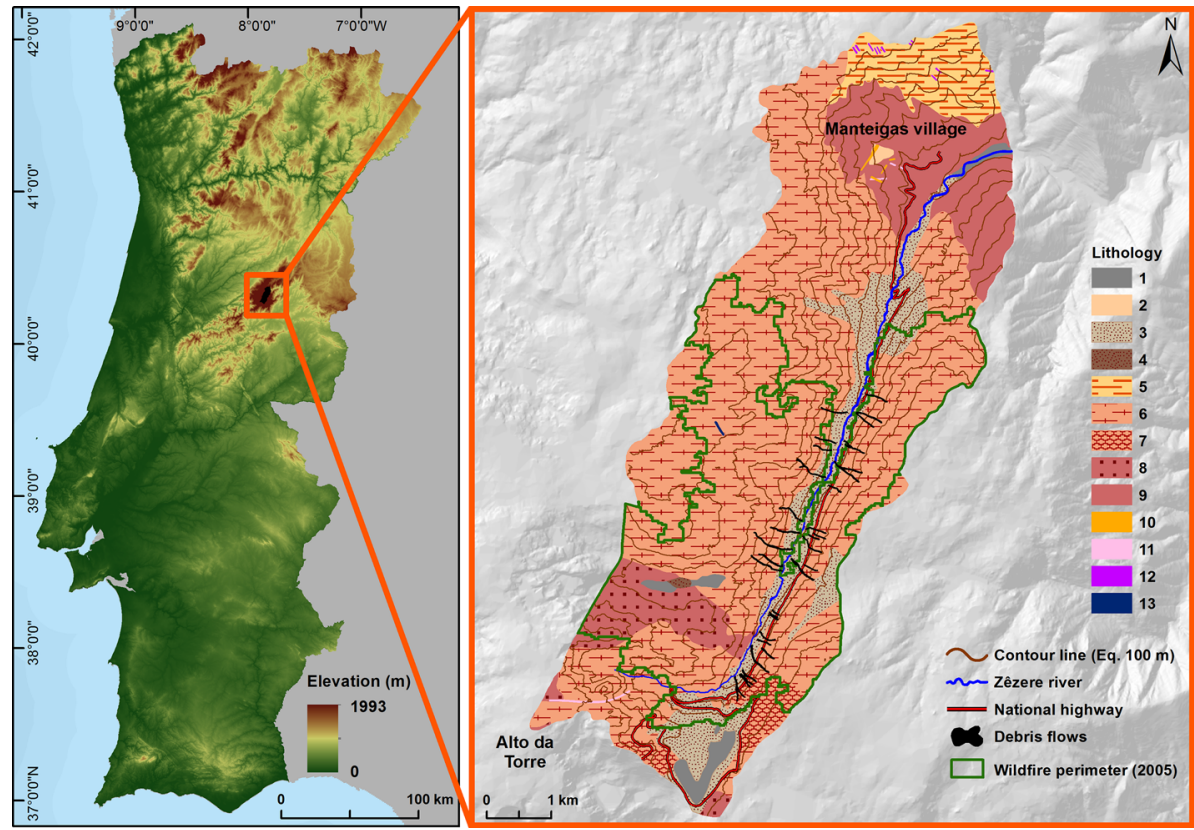

Fig. 1 Location of the study area, lithologhy and inventory of debris flows. Lithology: 1 alluvium; 2 slope deposits; 3 fluvioglacial deposits; 4 glacial deposits; 5 contact metamorphic rock (hornfels); 6 porphyritic medium- to coarse-grained two-mica granite; 7 porphyritic medium-grained two-mica granite; 8 nonporphyritic medium- to coarse-grained muscovite granite; 9 non-porphyritic medium- to fine-grained biotite granite; 10 quartz dikes; 11 basic rock dikes; 12 metamorphosed basic dikes; 13 aplite-pegmatite dikes 
an elevated plateau divided by two SSW-NNE trending valleys (Migoń and Vieira 2014). The study area, with about $44 \mathrm{~km}^{2}$, comprises one of these valleys (the Zêzere valley).

The geology is mainly granitic with a metamorphic aureole surrounding the northern and eastern basin margins (see Fig. 1). The study area is formed mainly by porphyritic medium- to coarse-grained two-mica granite and non-porphyritic medium- to fine-grained biotite granite (61.8 and $11.4 \%$ of the study area, respectively). Porphyritic mediumgrained two-mica granite $(2.2 \%)$ and non-porphyritic medium- to coarse-grained muscovite granite $(5.1 \%)$ can also be found in the study area. The metamorphic aureole $(5.2 \%)$ is formed by hornfels.

The altitude ranges between $1990 \mathrm{~m}$ a.s.l (Alto da Torre) and $668 \mathrm{~m}$ (Manteigas village) showing its gradual decreasing to NNE. The average altitude of the western- and easternfaced slopes of Zêzere valley is, respectively, 1348 and $1319 \mathrm{~m}$. In both sides of the valley, about $25 \%$ of the surface have angles between $25^{\circ}-35^{\circ}$, and $14 \%$ of the surface have angles above $35^{\circ}$. The climate is Mediterranean, with dry and warm summers. The wet season extends from October to May with a mean annual precipitation of about $2500 \mathrm{~mm}$ in the summit (Vieira et al. 2004). Snowfall can also occur in the winter, although less frequently than rainfall.

Part of the study area was affected by a huge wildfire during the summer of 2005, and the unprotected slopes were strongly affected by debris flow activity during the following rainy season. Although no victims were registered, the debris flows forced the closing of the national highway in the sector that links the main village to the most touristic places in the mountain. This was not the first time that a similar event happened in this region. In fact, the first reports on the occurrence of debris flows in the Zêzere valley and Manteigas village date back to the nineteenth century. In a particular event in 1804, two dozen lives were lost. One of the latest debris flow events, which happened before the one of 2005, was reported in 1993 and took place in an area affected by a wildfire 2 years before. Fortunately, no casualties were documented though a tourist facility was severely affected by the impact and deposition of debris, which caused very high material losses.

\section{Data and methods}

\subsection{Debris flow inventory}

A total of 34 debris flows occurred in 2005 were mapped (see Fig. 1), and 36 initiation areas were identified through the interpretation of morphological features from post-event digital topography, at a scale 1:10,000, and photo-interpretation of changes in vegetation patterns. In addition, the inventory was validated by field surveying during 2011 . The debris flows initiation areas are between 25 and $200 \mathrm{~m}^{2}$ wide, with an average of $100 \mathrm{~m}^{2}$, and a total area of $3700 \mathrm{~m}^{2}$. Despite some doubts regarding the absolute age of 3 inventoried debris flows, the inventory is assumed to be a debris flow event caused by a single rainfall trigger registered on 30 October 2005.

\subsection{Predisposing factors}

The following predisposing factors, selected according to the literature (e.g., Van Westen et al. 2008; Corominas et al. 2014) and the available data, were used as independent variables (Figs. 1,2): slope angle, slope aspect, inverse topographic wetness index (IWI), plan curvature, 

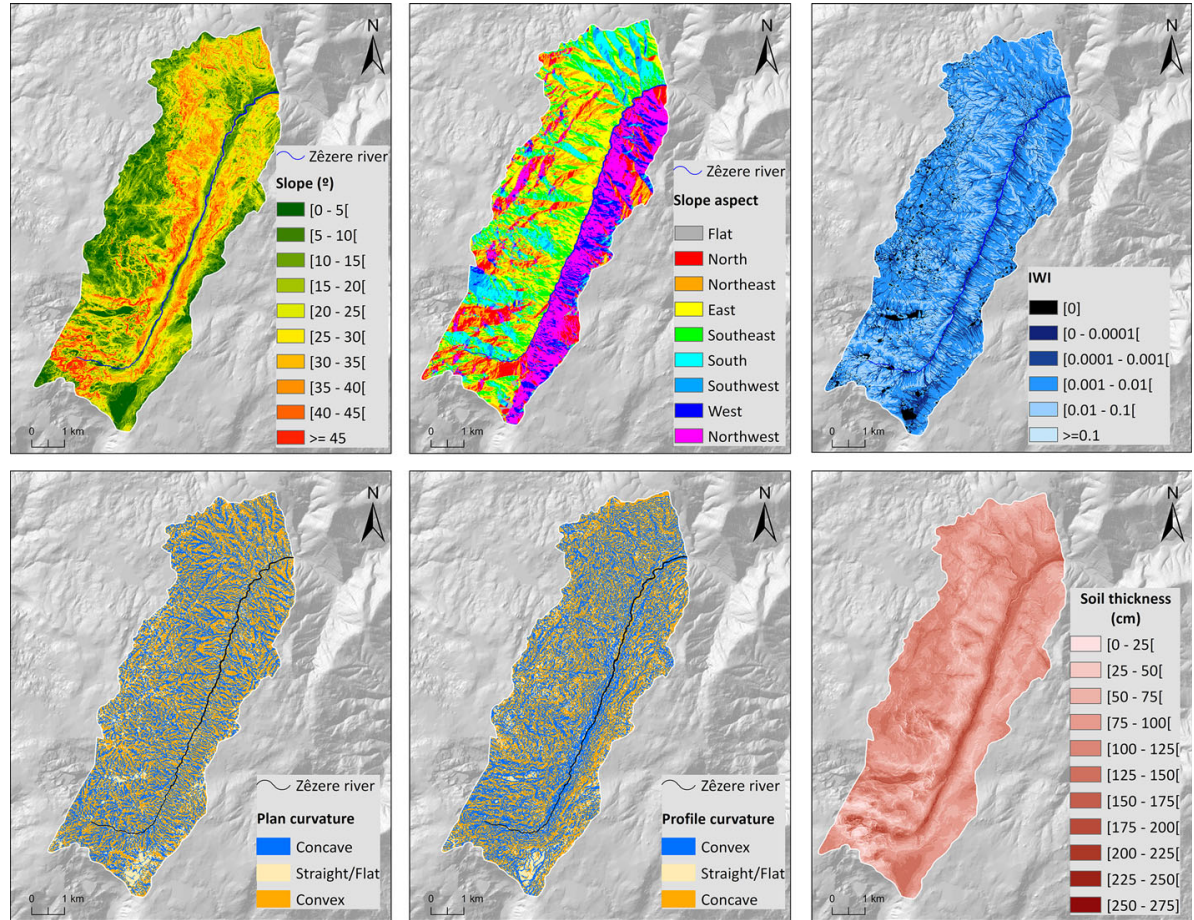

Fig. 2 Predisposing factors used as independent variables

profile curvature, soil thickness and lithology. The morphometric variables were derived from a pre-event DEM with a resolution of $5 \mathrm{~m}$. In this sense, these variables reflect the previous terrain conditions to the occurrence of debris flows, which is crucial to keep the meaning of the predisposing factor (Atkinson and Massari 1998; Clerici et al. 2010). The map of the soil thickness-interpreted in this study as the depth to bedrock-was based on the simplified geomorphologically indexed soil thickness (sGIST) model (Catani et al. 2010; Segoni et al. 2012). The model was validated by the comparison of the results with 38 field point measures, resulting in a mean absolute error of $29 \mathrm{~cm}$ and a mean relative error of 0.26 . The lithology (Fig. 1) was obtained from the official geological map of the region (1:50,000 scale).

\subsection{Susceptibility assessment of debris flow initiation}

The 34 inventoried debris flows are assumed to be related to the wildfire occurred in the summer of 2005 since they were all triggered inside the burned area (see Fig. 1). Thus, the susceptibility assessment of debris flow initiation using the logistic regression (LR) and the information value (IV) methods was performed within the burned perimeter, which covers $43.8 \%\left(19.3 \mathrm{~km}^{2}\right)$ of the basin.

\subsubsection{Logistic regression method}

The LR is one of the most widely used multivariate statistical methods to assess landslide susceptibility (e.g., Atkinson and Massari 1998; Guzzetti et al. 1999; Dai and Lee 2002; 
Süzen and Doyuran 2004; Ayalew and Yamagishi 2005; Gorsevski et al. 2006; Lee 2007; Carrara et al. 2008; Nefeslioglu et al. 2008; Van den Eeckhaut et al. 2006, 2010; Bai et al. 2010b, 2011; Das et al. 2010; Fressard et al. 2010; Bui et al. 2011; Schicker and Moon 2012; Kavzoglu et al. 2014). Unlike bivariate statistical analysis, the LR is not sensitive to the conditional dependence of the predisposing factors (Fressard et al. 2010). This is particularly important since the conditional dependence may lead to an overestimation of the spatial probability values (Blahut et al. 2010a, b).

The relationship between the dichotomous variable (i.e., the presence or absence of debris flow initiation areas) and the independent variables can be expressed according to Eq. 1 (e.g., Dai and Lee 2002)

$$
\operatorname{Pr}=1 /\left(1+\mathrm{e}^{-z}\right)
$$

where $\operatorname{Pr}$ is the spatial probability of the occurrence of debris flow initiation areas; $Z$ corresponds to the linear combination expressed by Eq. 2

$$
Z=B_{0}+B_{1} X_{1}+B_{2} X_{2}+\cdots+B_{n} X_{n}
$$

where $B_{0}$ is a constant; $B_{i}(i=1,2, \ldots, n)$ is the coefficient estimated; $n$ is the number of independent variables; and $X_{i}(i=1,2, \ldots, n)$ is the independent variable. Since $Z$ varies between $-\infty$ and $+\infty$, the probability ranges between 0 and 1 on an S-shaped curve.

The debris flow susceptibility assessment using the LR model included four basic steps (Bai et al. 2010a, b): (a) splitting the dataset into two groups (modeling and validation) and perform a data sampling of the debris flow-free areas; (b) multicollinearity diagnosis between the independent variables; (c) implementation of LR models; and (d) validation of the results.

The presence of the dependent variable is given by the 36 debris flow initiation areas identified. Considering the reduced number of presences, still subject of partitioning for modeling and validation purposes, the 36 initiation areas were randomly divided into three distinct groups with the same number of features (Table 1). The objective was to create three sets of LR models (Table 2) each one with two data groups for modeling and one for validation. Hence, each debris flow initiation area integrated the modeling and validation processes independently. The debris flow-free areas, i.e., where the dependent variable is absent (Table 2), were randomly sampled according to the total number of presences (Süzen and Doyuran 2004).

The $R^{2}$ ( $R$-square) and the variation inflation factor (VIF) were used to evaluate the correlation between the independent variables (O'Brien 2007). The former indicates the proportion of variance in a certain independent variable considering the other variables in the model. The VIF is defined as $1 /\left(1-R^{2}\right)$ and indicates the inflation of the estimated

Table 1 Separation of 36 debris flow initiation areas into three groups, for modeling and validation purposes

\begin{tabular}{lllc}
\hline & No. of presences (initiation areas) & Area $\left(\mathrm{m}^{2}\right)$ & No. of cells $(5 \mathrm{~m}$ resol.) \\
\hline Group 1 (G1) & 12 & 1275 & 51 \\
Group 2 (G2) & 12 & 1125 & 45 \\
Group 3 (G3) & 12 & 1300 & 52 \\
Total & 36 & 3700 & 148 \\
\hline
\end{tabular}


Table 2 Datasets (for LR and IV models) and absence data (for LR model)

\begin{tabular}{lllc}
\hline & Training & Validation & No. of cells with absence (5 m resol.) \\
\hline Dataset A & G1 + G2 & G3 & 96 \\
Dataset B & G1 + G3 & G2 & 103 \\
Dataset C & G3 + G2 & G1 & 97 \\
\hline
\end{tabular}

variance above what the variance would be if the independent variable was orthogonal to the other independent variables in the model (i.e., if $R^{2}=0$ ) (O'Brien 2007).

Twenty LR models were performed with each dataset, and new absence cells were sampled for each model. This number of models provided a general stabilization of the model's predictive capability. This procedure ensures robustness to the final spatial probability map, whose reliability could be compromised due to the reduced number of presences. For each dataset (A, B and C, Table 2), the mean probability of each set of 10 LR models was calculated. The predictive capability was evaluated through ROC curves and the quantification of the area under the curve (AUC) (Beguería 2006; Fawcett 2006). The ROC curves represent the balance between true positive rate (TPR) and false positive rate (FPR). Therefore, the TPR corresponds to the debris flow initiation area classified as susceptible and the FPR are areas not affected that were classified as susceptible. AUC values close to 1 indicate models with high precision, while 0.5 denotes a random classification.

The final spatial probability map results from the mean probability calculated for the 60 LR models. In addition, the final map was validated through a confusion matrix (Beguería 2006; Fawcett 2006) using a cutoff value of 0.5. All the cells sorted with a probability greater than 0.5 are considered unstable; thus, the value 1 is assigned. The remaining cells are stable (0). Moreover, the following ROC metrics were derived from the confusion matrix: efficiency, misclassification rate, sensitivity, specificity, false positive rate and false negative rate.

\subsubsection{Information value method}

The evaluation of the relative weight of each predisposing factor is a relevant step in every landslide susceptibility assessment. In bivariate analysis, each factor is individually combined with the dependent variable and the weighting values are calculated for each class based on the density of the dependent variable. To perform this type of analysis, we used the IV method, which has been applied with good results for landslide susceptibility assessment (e.g., Guillard and Zêzere 2012; Oliveira et al. 2015). For each of the independent variables, the IV is calculated from Eq. 3 (Yin and Yan 1988; Zêzere 2002)

$$
I i=\log \frac{S i / N i}{S / N}
$$

where $I i$ is the IV of the variable $i$; $S i$ is the number of terrain units with debris flow initiation areas (dependent variable) and simultaneously with the presence of variable $X i$ (predictive variable); $N i$ is the number of terrain units with the presence of variable $X i$; $S$ is the total number of terrain units with debris flow initiation areas; and $N$ is the total number of terrain units. When $S i=0$, the logarithmic normalization of $I i$ cannot be calculated. Hence, $I i$ is assumed to be the lowest value estimated considering all predictive variables. 
The total IV of a terrain unit $j$ (pixel with $5 \mathrm{~m}$ ) is calculated using Eq. 4

$$
I j=\sum_{i=0}^{m} X_{j i} I i
$$

where $m$ is the total number of variables; $X_{j i}$ is equal to 0 if the variable is not present in the terrain unit and equal to 1 if the variable is present.

Considering the datasets A, B and C (Tables 1, 2), 3 IV models were computed each one with two data groups for modeling and one for validation. The IV model does not take into account the sampling of absence cells since this is considered to be the entire study area without debris flows. The predictive capability of the three models was evaluated by ROC curves and the quantification of the AUC. The final susceptibility map results from the calculation of the mean scores for the $3 \mathrm{IV}$ models and was validated through a confusion matrix. In the IV method, the precision statistics derived from the confusion matrix are only valid for one specific operation point within the ROC space (Bradley 1997) which was defined by the Youden index $(J)$ (Perkins and Schisterman 2005):

$$
J=\operatorname{Maximum}\{\text { sensitivity }+ \text { specificity }-1\}
$$

The Youden index $(J)$ maximizes the accuracy as well as the vertical distance between the ROC curve and the diagonal of no discrimination (Jiménez-Valverde 2012).

The importance of each predisposing factor in the debris flow initiation was assessed by calculating and ranking two indexes: accountability (ACC) and reliability (REL). The ACC and REL indexes were introduced by Greenbaum et al. (1995a, b) and have been used by several authors (e.g., Blahut et al. 2010a; Garcia 2012; Oliveira 2012) as indicators of the relative importance each factor plays in predicting landslides. The ACC index calculation is based on the percentage of the total unstable area in each variable with higher relevance on the analysis (with IV $>0$ ). The REL index calculates the percentage area of a significant variable (with IV $>0$ ) that is unstable.

\subsection{Susceptibility assessment of debris flow run-out}

The debris flow run-out zones were modeled using two methods: the Flow-R model and the D-infinity downslope influence (DI) model.

The empirical model Flow-R allows the identification of debris flow initiation areas as well as the run-out simulation on medium and regional scale (Horton et al. 2008, 2011; Blahut et al. 2010b; Kappes et al. 2011; Baumann 2011; Fischer et al. 2012; Stalsberg et al. 2012; Quan Luna et al. 2014). This model has also been tested with other type of gravitational processes (Michoud et al. 2012; Van Westen et al. 2014). The identification of potential rupture zones is supported by an index-based method. The source data required are based on the DEM and derived variables and also on a set of user-defined parameters which are intended to reflect the conditions responsible for debris flows initiation. A detailed description on the automatic definition of potential initiation areas can be found at Horton et al. (2008, 2011, 2013). As an alternative, the model allows the input of initiation areas previously generated by other methods.

Once the potential initiation areas are defined it is possible to simulate the debris flow run-out. The process involves a combination of probabilistic and energy algorithms. The first one intends to define the flow path, whereas the latter sets the maximum run-out distance (Horton et al. 2008, 2011). Thus, for each potential initiation area the surface affected by the passage and deposition of the debris flow is defined. Given the difficulty in 
estimating the erosion and deposition along the path at a regional scale, the debris volume is not considered in the analysis (Horton et al. 2011).

In Flow-R model, the user selects the most appropriate calibration parameters according to the type of landslide. As source data, a pre-event DEM with a resolution of $5 \mathrm{~m}$ and a file with the 36 initiation areas were used.

For the probabilistic definition of flow direction, the Holmgren algorithm (Eq. 6) was applied (Holmgren 1994; Horton et al. 2008, 2011, 2013; Blahut et al. 2010b; Baumann 2011; Kappes et al. 2011; Fischer et al. 2012; Quan Luna et al. 2014; Van Westen et al. 2014).

$$
f_{s i}=\frac{\left(\tan \beta_{i}\right)^{X}}{\sum_{j=1}^{8}\left(\tan \beta_{j}\right)^{X}} \quad \text { for } \tan \beta>0
$$

where $i, j=$ flow directions $(1 . .8) ; f_{s i}=$ flow proportion $(0 . .1)$ in direction $i$; $\tan \beta=$ slope gradient between the central cell and cell in direction $i$; and $X=$ variable exponent. The Holmgren algorithm allows controlling the debris flow spreading by changing the values of the exponent. For instance, the lower the value of the exponent, the wider the spreading of the flow. Following the proposal of Holmgren (1994), we performed the simulations with exponent variation between 4 and 6 .

The assessment of the run-out distance is based on a unit energy balance (Eq. 7), a constant lost function and a maximum threshold (Horton et al. 2008, 2013; Blahut et al. 2010b; Baumann 2011; Kappes et al. 2011).

$$
E_{\mathrm{kin}}^{i}=E_{\mathrm{kin}}^{i-1}+\Delta E_{\mathrm{pot}}^{i}-E_{\mathrm{loss}}^{i}
$$

where $E_{\text {kin }}=$ kinetic energy; $E_{\text {pot }}=$ change in potential energy; $E_{\text {loss }}=$ energy loss in friction; $i=$ time step.

The constant friction loss corresponds to the average slope angle between the source area and the most distant point reached by the flow along its path, which is the equivalent of the angle of reach (Corominas 1996). Considering the range of values reported in the literature (e.g., Blahut et al. 2010b; Kappes et al. 2011; Lari et al. 2011; Fischer et al. 2012), angles of reach between $5^{\circ}$ and $15^{\circ}$ were selected to simulate the maximum distance traveled.

It was also necessary to define a velocity threshold corresponding to the maximum velocity achieved by debris flows in the study area. The lack of information regarding this parameter led to establishing a maximum limit of $15 \mathrm{~m} \mathrm{~s}^{-1}$. This threshold was based on the maximum velocities observed in Swiss Alps, whose values ranged between 13 and $14 \mathrm{~m} \mathrm{~s}^{-1}$ (Rickenmann and Zimmermann 1993). However, to limit the number of simulations velocities of 2,5,10 and $15 \mathrm{~m} \mathrm{~s}^{-1}$ were only considered. To simulate the run-out of the 36 debris flow initiation areas, 132 models were performed in order to integrate all possible parameter combinations mentioned above.

The TauDEM software (Tarboton 1997) is a set of tools that enable the extraction and analysis of hydrological information from the DEM. Some of these tools allow for automatically define the potential trajectory of the debris flow run-out, using pre-defined initiation areas.

Following the methodology developed by Guinau et al. (2007), two tools were used from the TauDEM software: the D-infinity flow direction $(\mathrm{D} \infty)$ and the $\mathrm{D}$-infinity downslope influence (DI). The $\mathrm{D} \infty$ assigns multiple flow directions to each cell based on the steepest downward slope. A detailed description of the algorithm can be found at Tarboton (1997). The DI is used to trace the expected trajectory of the sediments, from a 
particular source, taking into account the flow direction in each downstream cell. The contribution resulting from a set of source cells can follow different paths, according to the multiple flow directions. Plus, the level of influence along the paths may decrease with the distance if the input source is spread by a large number of cells with divergent flow (Tarboton 2003; Tarboton and Baker 2008).

The input data required for the DI model consists in a pre-event DEM with a resolution of $5 \mathrm{~m}$ and a binary file with the definition of the debris flow initiation areas. The flow directions are calculated through the $\mathrm{D} \infty$ tool. Therefore, based on this model, the DI defines the potential trajectories of the debris flows from a specific source. Overall, the model calculates the flow concentration in each cell from its origin to the culmination into the drainage network, where the concentration reaches its highest values. To optimize the result, the flow lines generated by the model were eliminated from the moment they reached a principal watercourse, such as Zêzere river.

\subsection{Susceptibility assessment of debris flow initiation and run-out at the basin scale in a scenario of a recent wildfire}

Although relevant progress has been made on the run-out modeling of past debris flows (e.g., Remaître et al. 2005; Beguería et al. 2009; Quan Luna et al. 2011; Hussin et al. 2012; Van Asch et al. 2014), the research focused on the run-out modeling of potential debris flows at the basin scale is more scarce (Guinau et al. 2007; Blahut et al. 2010b; Kappes et al. 2011; Horton et al. 2011; Quan Luna et al. 2016).

The construction of the final debris flow susceptibility map at the basin scale, integrating both the initiation and the run-out areas in a scenario of a recent wildfire, included the following steps:

1. Elaboration of a spatial probability map for the complete basin area using the mean value of the constant $\left(B_{0}\right)$ and the coefficient estimated $\left(B_{i}\right)$ for each independent variable, considering the $60 \mathrm{LR}$ models computed for the burned area;

2. Elaboration of a susceptibility map for the complete basin area using the mean value of the scores obtained for each class of each independent variable, considering the 3 IV models computed for the burned area;

3. Selection and merging of the $1 \%$ of the basin area with the highest values obtained in each statistical model computed in (1) and (2). Plus, the areas with less than $500 \mathrm{~m}^{2}$ were excluded in order to obtain spatially consistent zones. With this criterion, we assume that isolated small groups of pixels may not have a significant meaning for the susceptibility assessment at the basin scale. Although we have tested the automatic generation of debris flow initiation areas with the Flow-R model (not shown in this work), we believe the result overestimates these areas, defining potential ruptures along the path of almost every stream. Moreover, the result does not define a susceptibility level. For these reasons, we decided to use the initiation areas previously generated and validated using the LR and IV models;

4. The new debris flow initiation areas obtained in (3) were used as input for the run-out simulation with Flow-R and DI models. For the former, the parameters selected were the same that produced the most reliable result during the calibration phase of the 34 debris flows occurred in 2005. The results from both models were reclassified into quartiles associated with different susceptibility levels to allow their comparison;

5. The spatial agreement between the run-out models computed in (4) was evaluated using the kappa coefficient (Cohen 1960) for two different conditions: (a) the output of 
both models was classified into susceptible and non-susceptible, without individualizing levels of susceptibility; (b) the output of both models was classified into quartile susceptibility classes and the agreement was assessed for the overlapped area.

\section{Results and discussion}

\subsection{Susceptibility assessment of debris flow initiation}

The multicollinearity diagnosis is summarized in Table 3. Some authors (e.g., Van den Eeckhaut et al. 2006; Bai et al. 2010a, b, 2011) suggest that values of VIF > 2 indicate multicollinearity; therefore, the variables should be excluded from the models. Other authors (e.g., Bui et al. 2011; Kavzoglu et al. 2014) refer values of VIF > 10. Looking at the VIF and $R^{2}$ obtained in Table 3, we can somehow assume a correlation between the variables slope angle and soil thickness. For instance, $R^{2}$ indicates that $53 \%$ of the total variation in one of the variables can be explained by the other one. However, we did not consider these values high enough to justify any exclusion; thus, we have decided to keep both slope angle and soil thickness in all models.

\subsubsection{LR models}

The ROC curves and AUC values (Fig. 3) show the high predictive capability of each set of $10 \mathrm{LR}$ models performed in the datasets (AUC ranging from 0.91 to 0.98 ). The final spatial probability model for the debris flow initiation within the burned perimeter (Fig. 4) results from the mean probability estimated for a total of $60 \mathrm{LR}$ models computed with the three datasets referred in Sect. 3.3.1. The final model was reclassified in six classes representing the percentage of the study area with the highest values of spatial probability (Fig. 4). The confusion matrix (Table 4) and its derived statistics (Table 5) reflect the robustness of the final spatial probability model. Regarding the overall unstable area, 140 cells $\left(3500 \mathrm{~m}^{2}\right)$ were classified as true positive, whereas only 8 cells $\left(200 \mathrm{~m}^{2}\right)$ were misclassified. Although $8 \%$ were considered false positive, it must be kept in mind that false positives do not necessarily mean a classification error. It may represent debris flow-

Table 3 Multicollinearity diagnosis between the independent variables

\begin{tabular}{|c|c|c|c|c|c|c|c|c|}
\hline \multicolumn{8}{|l|}{$\overline{R^{2}}$} & \multirow[t]{2}{*}{ VIF } \\
\hline $\begin{array}{l}\text { Independent } \\
\text { variables }\end{array}$ & $\begin{array}{l}\text { Slope } \\
\text { aspect }\end{array}$ & Lithology & $\begin{array}{l}\text { Profile } \\
\text { curv. }\end{array}$ & $\begin{array}{l}\text { Plan } \\
\text { curv. }\end{array}$ & $\begin{array}{l}\text { Slope } \\
\text { angle }\end{array}$ & $\begin{array}{l}\text { Soil } \\
\text { thickness }\end{array}$ & IWI & \\
\hline Slope aspect & 1.000 & 0.048 & 0.080 & 0.029 & 0.0005 & 0.011 & 0.0003 & 1.17 \\
\hline Lithology & & 1.000 & 0.007 & 0.003 & 0.009 & 0.005 & 0.003 & 1.09 \\
\hline Profile curv. & & & 1.000 & 0.055 & 0.001 & 0.044 & 0.008 & 1.23 \\
\hline Plan curv. & & & & 1.000 & 0.053 & 0.015 & 0.016 & 1.16 \\
\hline Slope angle & & & & & 1.000 & 0.531 & 0.274 & 2.78 \\
\hline Soil thickness & & & & & & 1.000 & 0.148 & 2.36 \\
\hline IWI & & & & & & & 1.000 & 1.42 \\
\hline
\end{tabular}




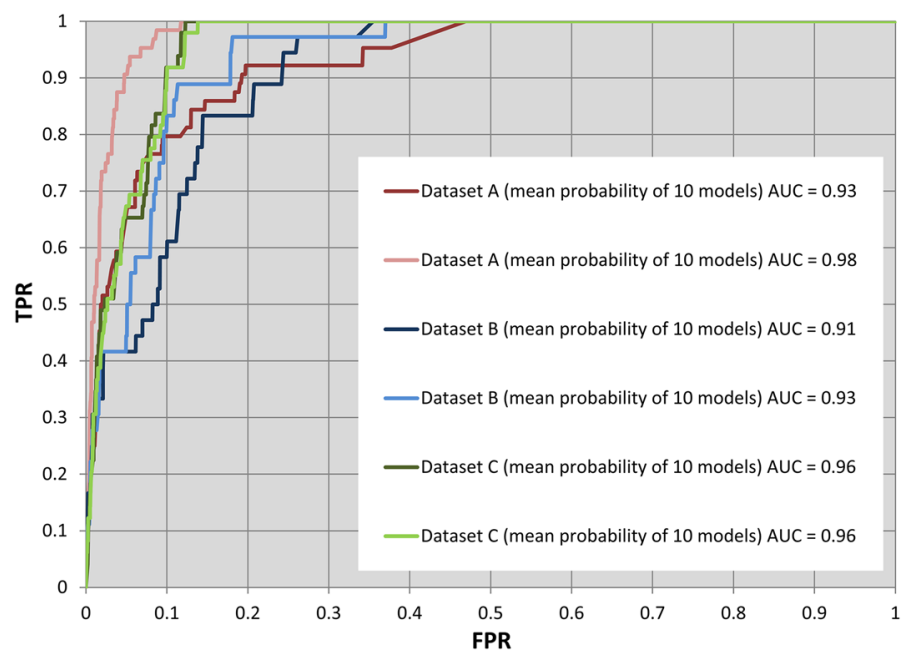

Fig. 3 ROC curves and AUC estimation for the LR models

prone areas where the geomorphological instability not yet occurred. Ultimately, the sensitivity (95\%) and specificity (92\%) of the model indicate its high accuracy.

For each cell, Fig. 5 relates the mean probability value of the 60 LR models ranked with the variation measured by one standard deviation $(1 \sigma)$ of the obtained probability estimate (Guzzetti et al. 2006; Van den Eeckhaut et al. 2009). The measure of $1 \sigma$ is relatively low for cells classified with low and high probability and more significant for the intermediate values. However, the dispersion of the estimated values is negligible and only a few cells have a significant variability. This demonstrates the capability of the model to reliably classify the susceptible areas as well as the non-susceptible. The variation of the model can be represented by the equation in Fig. 5. The correlation between the two estimates is high $\left(R^{2}=0.93\right)$ which indicates its similarity (Guzzetti et al. 2006).

Table 6 summarizes the cumulative percentage of unstable area verified in each class of the final spatial probability model. It is clear that the $1 \%$ of the study area with the highest values of spatial probability integrates $64 \%$ of the unstable area, i.e., the debris flow initiation areas. If we consider 5\%, the cumulative unstable area reaches $98 \%$.

\subsubsection{IV models}

Table 7 shows the results of the application of Eq. 3 for each dataset (A, B and C, Table 2). The classes of the predisposing factors standing out as the most relevant for the debris flow initiation are the following: concave areas (for both plan and profile curvature); slope aspect faced NW; slope angle higher than $35^{\circ}$; low values of IWI (except IWI $=0$ ); porphyritic medium-grained two-mica granite; and soil thickness up to $75 \mathrm{~cm}$.

Table 8 shows the ranking of predisposing factors according to the ACC and REL indexes. The ranking was calculated based on the sum of the ordered indexes. The slope angle is the most important factor, followed by plan curvature, soil thickness and lithology. These results are in line with the controlling factors pointed out in several previous studies (e.g., Wohl and Pearthree 1991; Cannon and Reneau 2000; Cannon 2001; Cannon et al. $2001 \mathrm{~b}, 2010)$ as related to the occurrence of debris flows in burned areas, such as the basin 


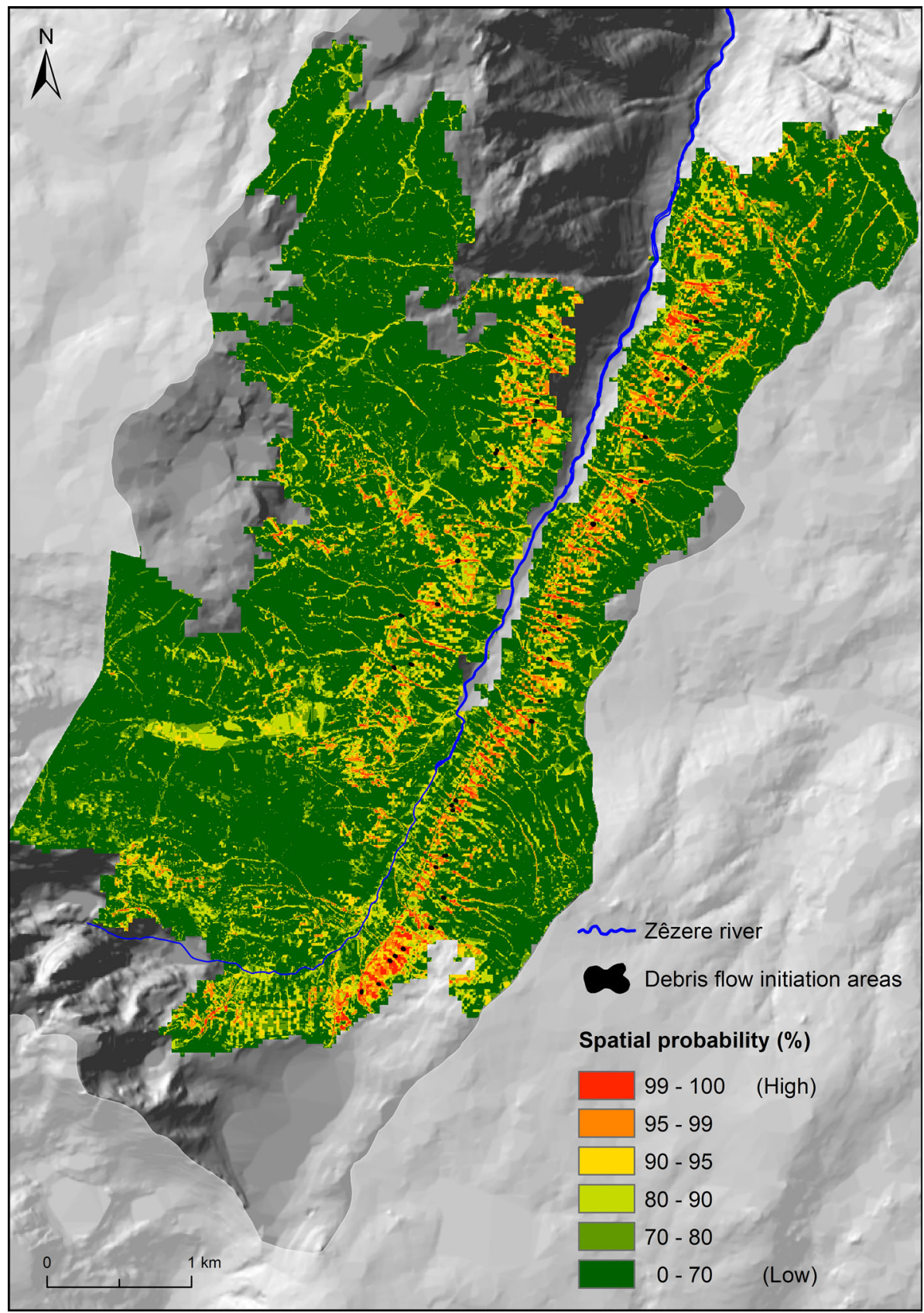

Fig. 4 Spatial probability model for debris flow initiation (mean probability from 60 LR models)

morphology, the lithology and the soil thickness, among other variables not included in the present research due to the lack of data. The predisposing factors with less influence in debris flow initiation are the profile curvature and the IWI. 
Table 4 Confusion matrix of the final spatial probability model of debris flow initiation within the burned perimeter, using the LR method

Observed

$\overline{\text { Debris flow initiation area (1) No debris flow initiation area (0) }}$

Predicted

Debris flow initiation area (1)

140

63,413

No debris flow initiation area (0)

8

705,344

Table 5 Precision statistics derived from the confusion matrix (LR model)

\begin{tabular}{lll}
\hline Efficiency & $(\mathrm{TP}+\mathrm{TN}) /(\mathrm{TP}+\mathrm{FP}+\mathrm{FN}+\mathrm{TN})$ & 0.92 \\
Misclassification rate & $(\mathrm{FP}+\mathrm{FN}) /(\mathrm{TP}+\mathrm{FP}+\mathrm{FN}+\mathrm{TN})$ & 0.08 \\
Sensitivity & $\mathrm{TP} /(\mathrm{TP}+\mathrm{FN})$ & 0.95 \\
Specificity & $\mathrm{TN} /(\mathrm{FP}+\mathrm{TN})$ & 0.92 \\
False positive rate & $\mathrm{FP} /(\mathrm{FP}+\mathrm{TN})$ & 0.08 \\
False negative rate & $\mathrm{FN} /(\mathrm{TP}+\mathrm{FN})$ & 0.05 \\
\hline
\end{tabular}

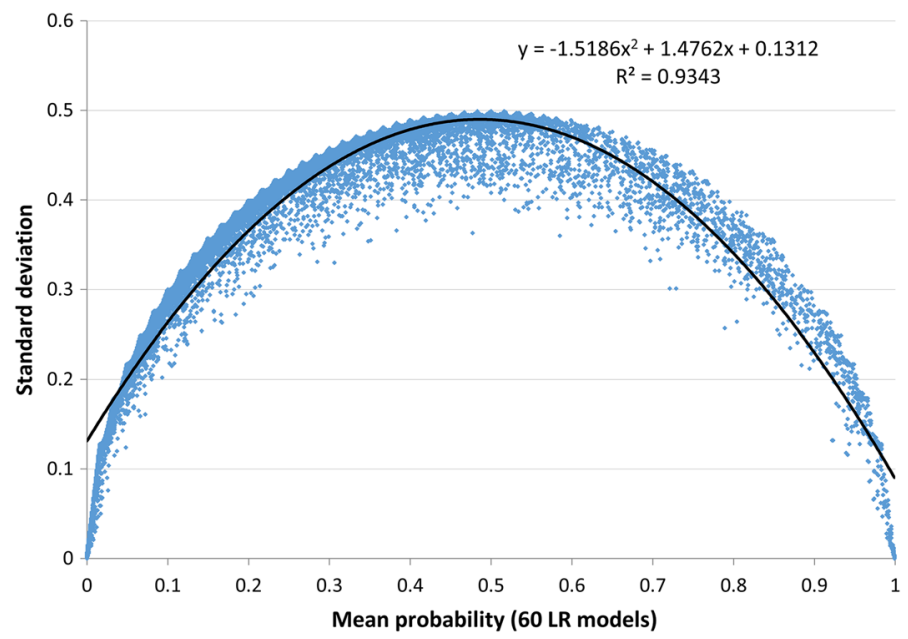

Fig. 5 Mean value of 60 probability estimates ( $x$-axis) against one standard deviation $(1 \sigma)$ of the probability estimate ( $y$-axis)

The ROC curves and AUC values computed for the 3 IV models are shown in Fig. 6 and indicate a high predictive capability of the models computed with each dataset, although not so high as the ones obtained with the LR models (AUC ranging from 0.91 to 0.94). The final susceptibility model for debris flow initiation within the burned perimeter (Fig. 7) results from the mean scores obtained with the 3 IV models. The final model was also reclassified in 6 classes representing the percentage of the study area with the highest values of susceptibility, to facilitate the comparison with the final model obtained with the LR method. The confusion matrix (Table 9) and its derived statistics (Table 10) show good results, which can be proved by the sensitivity (92\%) and specificity (91\%) of the model, 
Table 6 Percentage of the study area with the highest values of spatial probability (LR model) versus cumulative percentage of unstable area

\begin{tabular}{llll}
\hline $\begin{array}{l}\% \text { of the study area with the highest values } \\
\text { of probability }\end{array}$ & $\begin{array}{l}\text { Probability } \\
\text { values }\end{array}$ & $\begin{array}{l}\text { Cumulative } \\
\text { unstable area }\left(\mathrm{m}^{2}\right)\end{array}$ & $\begin{array}{l}\text { Cumulative \% of } \\
\text { unstable area }\end{array}$ \\
\hline $99-100$ & {$[0.91-1.0]$} & 2375 & 64.2 \\
$95-99$ & {$[0.64-0.91]$} & 3225 & 87.2 \\
$90-95$ & {$[0.45-0.64]$} & 3625 & 98.0 \\
$80-90$ & {$[0.25-0.45]$} & 3700 & 100 \\
$70-80$ & {$[0.14-0.25]$} & 3700 & 100 \\
$0-70$ & {$[0-0.14]$} & 3700 & 100 \\
\hline
\end{tabular}

although these results do not surpass the ones obtained with the LR method. In fact, with the IV method the misclassification rate was $1 \%$ higher as well as the false positive rate. The false negative rate was $3 \%$ higher. Table 11 summarizes the cumulative percentage of unstable area verified in each susceptibility class of the final susceptibility model. The $1 \%$ of the study area with the highest values of susceptibility integrates $46.6 \%$ of the debris flow initiation areas, almost $18 \%$ less comparing with the LR model. However, the difference between the models is less expressive if we consider the $5 \%$ of the study area with the highest values of susceptibility (ca. 6\%).

\subsection{Susceptibility assessment of debris flow run-out}

The validation of the run-out models was performed by comparing the results with the spatial pattern of the 34 debris flows registered along the Zêzere valley. The true positive and false negative rates were calculated for each model.

Concerning the Flow-R model, Fig. 8 shows the sensitive analysis of the calibration parameters, given by the range values of the true positive rate within 132 run-out models. When the same Holmgren exponent value is applied, sensitivity rises with maximum velocity increasing but reduces with angle of reach increasing. The same tendency is observed with any exponent used, though true positive rate globally decreases over the increasing exponent value. When maximum velocities of 2 and $5 \mathrm{~m} \mathrm{~s}^{-1}$ are considered, the angles of reach between $5^{\circ}$ and $7^{\circ}$ correctly validate a higher percentage of debris flow area. However, from the maximum velocity of $10 \mathrm{~m} \mathrm{~s}^{-1}$ any angle value applied validates the same percentage of area. Overall, the model with lower true positive rate $(53.7 \%)$ and highest percentage of false negatives $(46.3 \%)$ was performed using a Holmgren exponent of 6 , an angle of reach of $15^{\circ}$ and a maximum velocity of $2 \mathrm{~m} \mathrm{~s}^{-1}$. On the other hand, the models with highest sensitivity $(83.5 \%)$ used an exponent of 4 , angles of reach between $5^{\circ}$ and $15^{\circ}$ and maximum velocities of 10 and $15 \mathrm{~m} \mathrm{~s}^{-1}$. The model response to the variations of the Holmgren exponent and different angles of reach is more sensitive when the maximum velocity defined is below $10 \mathrm{~m} \mathrm{~s}^{-1}$.

The most accurate model, with the highest percentage of correctly classified debris flow area and simultaneously fewer false positive occurrences, was the result of the following calibration parameters: Holmgren exponent of 4, angle of reach of $11^{\circ}$ and maximum velocity of $10 \mathrm{~m} \mathrm{~s}^{-1}$. This combination provided less $8 \%$ of false positive area compared to other models with equal sensitivity. The result can be interpreted as a spatial probability, although in a qualitative way (Horton et al. 2011). 
Table 7 Susceptibility scores of predisposing factor classes computed with the IV method for three datasets (A, B and C)

\begin{tabular}{|c|c|c|c|c|c|}
\hline \multirow{2}{*}{$\begin{array}{l}\text { Predisposing } \\
\text { factor } \\
\text { Plan curvature }\end{array}$} & \multicolumn{2}{|c|}{ Classes } & \multirow{2}{*}{$\begin{array}{l}\begin{array}{l}\text { IV } \\
\text { (dataset } \\
\text { A) }\end{array} \\
0.8\end{array}$} & \multirow{2}{*}{$\begin{array}{l}\begin{array}{l}\text { IV } \\
\text { (dataset } \\
\text { B) }\end{array} \\
0.8\end{array}$} & \multirow{2}{*}{$\begin{array}{l}\begin{array}{l}\text { IV } \\
\text { (dataset } \\
\text { C) }\end{array} \\
0.8\end{array}$} \\
\hline & 1 & Concave & & & \\
\hline & 2 & Straight/flat & -2.2 & -2.2 & -2.2 \\
\hline & 3 & Convex & -2.2 & -1.6 & -1.7 \\
\hline \multirow{3}{*}{$\begin{array}{l}\text { Profile } \\
\text { curvature }\end{array}$} & 1 & Convex & -0.2 & 0.0 & -0.2 \\
\hline & 2 & Straight/flat & -2.2 & -1.1 & -0.9 \\
\hline & 3 & Concave & 0.4 & 0.2 & 0.3 \\
\hline \multirow[t]{9}{*}{ Slope aspect } & 1 & Flat & -2.2 & -2.2 & -2.2 \\
\hline & 2 & North & 0.3 & 0.5 & -0.7 \\
\hline & 3 & Northeast & 0.0 & 0.0 & -0.1 \\
\hline & 4 & East & 0.2 & -0.1 & 0.3 \\
\hline & 5 & Southeast & -1.3 & -1.6 & -1.0 \\
\hline & 6 & South & -2.2 & -2.2 & -2.2 \\
\hline & 7 & Southwest & -2.2 & -2.2 & -2.2 \\
\hline & 8 & West & -0.6 & -0.7 & 0.2 \\
\hline & 9 & Northwest & 0.7 & 0.8 & 0.7 \\
\hline \multirow[t]{10}{*}{ Slope angle $\left({ }^{\circ}\right)$} & 1 & $0-5$ & -2.2 & -2.2 & -2.2 \\
\hline & 2 & $5-10$ & -2.2 & -2.2 & -2.2 \\
\hline & 3 & $10-15$ & -2.2 & -2.2 & -2.2 \\
\hline & 4 & $15-20$ & -2.2 & -2.1 & -1.5 \\
\hline & 5 & $20-25$ & -1.3 & -2.0 & -0.9 \\
\hline & 6 & $25-30$ & -0.9 & -0.8 & 0.3 \\
\hline & 7 & $30-35$ & 0.2 & 0.6 & 0.0 \\
\hline & 8 & $35-40$ & 1.1 & 1.0 & 0.9 \\
\hline & 9 & $40-45$ & 1.7 & 1.7 & 1.7 \\
\hline & 10 & $>45$ & 2.2 & 2.0 & 1.8 \\
\hline \multirow[t]{6}{*}{ IWI } & 1 & 0 & -2.2 & -2.2 & -2.2 \\
\hline & 2 & $0-0.0001$ & 1.5 & 1.3 & 2.3 \\
\hline & 3 & $0.0001-0.001$ & 0.3 & 0.3 & 0.6 \\
\hline & 4 & $0.001-0.01$ & -0.5 & -0.6 & -0.9 \\
\hline & 5 & $0.01-0.1$ & 0.2 & 0.4 & -0.1 \\
\hline & 6 & $0.1-1.2$ & 1.5 & 1.6 & -2.2 \\
\hline \multirow[t]{7}{*}{ Lithology } & 1 & Alluvium & -2.2 & -2.2 & -2.2 \\
\hline & 3 & Fluvioglacial deposits & -0.6 & -1.4 & -1.2 \\
\hline & 4 & Glacial deposits & -2.2 & -2.2 & -2.2 \\
\hline & 6 & $\begin{array}{l}\text { Porphyritic medium- to coarse-grained two- } \\
\text { mica granite }\end{array}$ & 0.0 & 0.0 & 0.0 \\
\hline & 7 & $\begin{array}{l}\text { Porphyritic medium-grained two-mica } \\
\text { granite }\end{array}$ & 2.1 & 2.4 & 2.3 \\
\hline & 8 & $\begin{array}{l}\text { Non-porphyritic medium- to coarse-grained } \\
\text { muscovite granite }\end{array}$ & -2.2 & -2.2 & -2.2 \\
\hline & 13 & Aplite-pegmatite dikes & -2.2 & -2.2 & -2.2 \\
\hline
\end{tabular}


Table 7 continued

\begin{tabular}{lllllr}
\hline $\begin{array}{l}\text { Predisposing } \\
\text { factor }\end{array}$ & Classes & $\begin{array}{l}\text { IV } \\
\text { (dataset } \\
\text { A) }\end{array}$ & $\begin{array}{l}\text { IV } \\
\text { (dataset } \\
\text { B) }\end{array}$ & $\begin{array}{l}\text { IV } \\
\text { (dataset } \\
\text { C) }\end{array}$ \\
\hline $\begin{array}{l}\text { Soil thickness } \\
(\mathrm{cm})\end{array}$ & 1 & $0-25$ & 2.4 & 2.0 & -2.2 \\
& 2 & $25-50$ & 1.4 & 1.3 & 1.3 \\
& 3 & $50-75$ & 0.7 & 0.8 & 0.7 \\
& 4 & $75-100$ & -1.5 & -0.8 & -0.7 \\
& 5 & $100-125$ & -2.2 & -2.2 & -2.2 \\
& 6 & $125-150$ & -0.1 & -2.2 & -0.3 \\
& 7 & $150-175$ & -2.2 & -2.2 & -0.9 \\
& 8 & $175-200$ & -2.2 & -2.2 & -2.2 \\
& 9 & $200-225$ & -2.2 & -2.2 & -2.2 \\
& 10 & $225-250$ & -2.2 & -2.2 & -2.2 \\
& 11 & $250-275$ & -2.2 & -2.2 & -2.2 \\
\hline
\end{tabular}

Table 8 Calculation and hierarchy of accountability (ACC) and reliability (REL) indexes (mean values obtained for the 3 IV models)

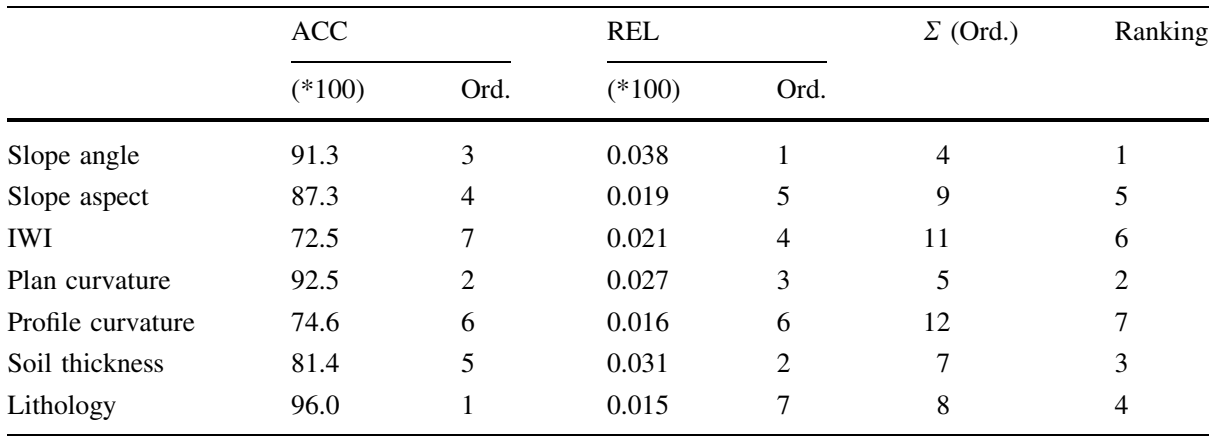

To allow the comparison of the outcomes, the Flow-R and DI model outputs were reclassified into quartiles associated with different levels of susceptibility (Table 12) identifying the areas more or less prone to the passage and deposition of debris flows. Consequently, the different levels of susceptibility can be interpreted as a proxy of the debris flow magnitude, which the models do not take into account (Blahut et al. 2010b). Figures 9 and 10 show the run-out modeling performed with Flow-R and DI models.

The comparison between the run-out modeling and the spatial pattern of the 34 debris flows that occurred along the Zêzere valley allows estimating a sensitivity (i.e., the proportion of positive cases correctly predicted) around $83.5 \%$ for the Flow-R model (Fig. 9) and $80.5 \%$ for the DI model (Fig. 10). On the other hand, the false negative rate $(16.5 \%$ in Flow-R and $19.5 \%$ in DI) reflects the areas affected by the passage and deposition of the mobilized material but interpreted by the models as non-susceptible areas.

Considering the 34 debris flows, Figs. 11 and 12 show the percentage of run-out area classified by the models as susceptible (true positive) or as non-susceptible (false negative), as well as the percentage of area obtained in each susceptibility class. In relation to Flow- 


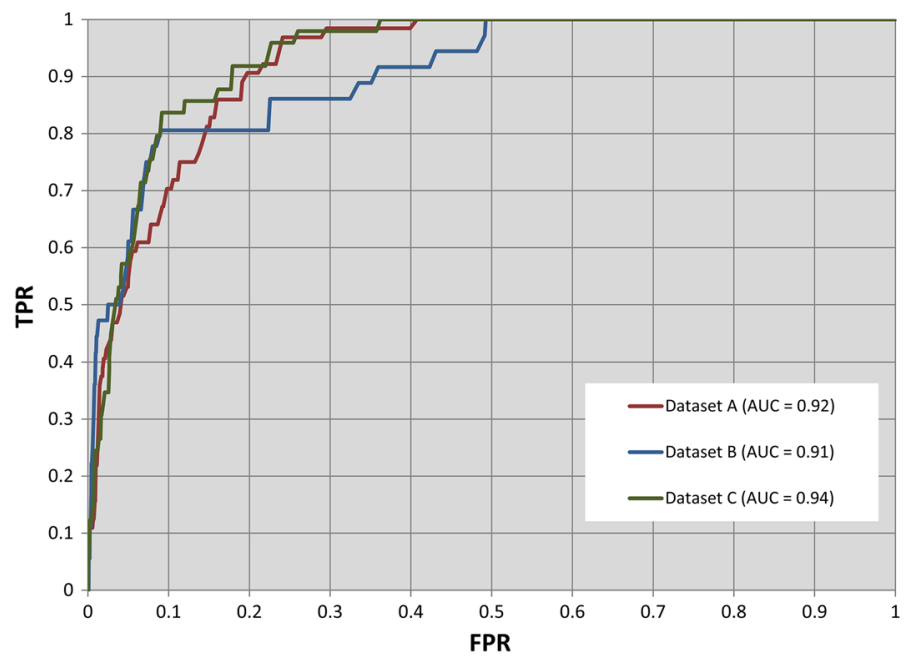

Fig. 6 ROC curves and AUC estimation for the IV models

$\mathrm{R}$, debris flow \#2 has the highest percentage of incorrectly classified area (43.8\%) followed by debris flows \#6, \#15,\#21 and \#29, each one with more than $20 \%$ of the area classified as false negative (Fig. 11). In the DI model, debris flow \#2 has also the highest percentage of misclassified area (56.3\%) followed by \#6, \#21, \#22 and \#30 with a false negative area equal or greater than $30 \%$ (Fig. 12). Concerning debris flow \#2, both models failed to define the run-out path at the end of the traveled distance. In \#6, there is a slight discrepancy between the results of the Flow-R model and the spatial delimitation of the debris flow pattern, especially near the sector where the drainage channel shows an inflection. In DI model, the erosion dissection of the drainage network is represented by a very well defined flow line; hence, the debris flow real width is underestimated. Also in debris flow \#22, which diverges due to a topographic obstacle, the DI defines the stream channel as the susceptible path, while the Flow-R classifies the diverging area with medium or low susceptibility. Debris flow \#30 is fully covered by all susceptibility classes in Flow-R model, whereas in DI, $38.2 \%$ is accounted as false negative.

Despite the previous results, the visual analysis (Figs. 9, 10) shows that the differences between the debris flows modeled areas and the real affected ones are not substantially significant and often occurs at the end of the propagation distance. This situation is not unusual, since the debris flows tend to easily change direction after leaving the drainage channel. Other false negative occurrences are related to the inflection sectors of the drainage network, where the models do not properly estimate the lateral spread of the debris flows. However, the errors obtained with both models do not come from flow paths definition completely different from the observed ones. It can be seen as small inconsistencies between the modeling results and the reality, reflecting the limitations of the DEM.

Nevertheless, the area classified as false negative is below $5 \%$ in $67.6 \%$ of the debris flows modeled with Flow-R as well as in $35.3 \%$ simulated with DI. Overall, $97.1 \%$ of the debris flow simulated with Flow-R and $88.2 \%$ with DI have at least $70 \%$ of the area correctly classified. Concerning the high and very high susceptibility, $73.5 \%$ of the debris 


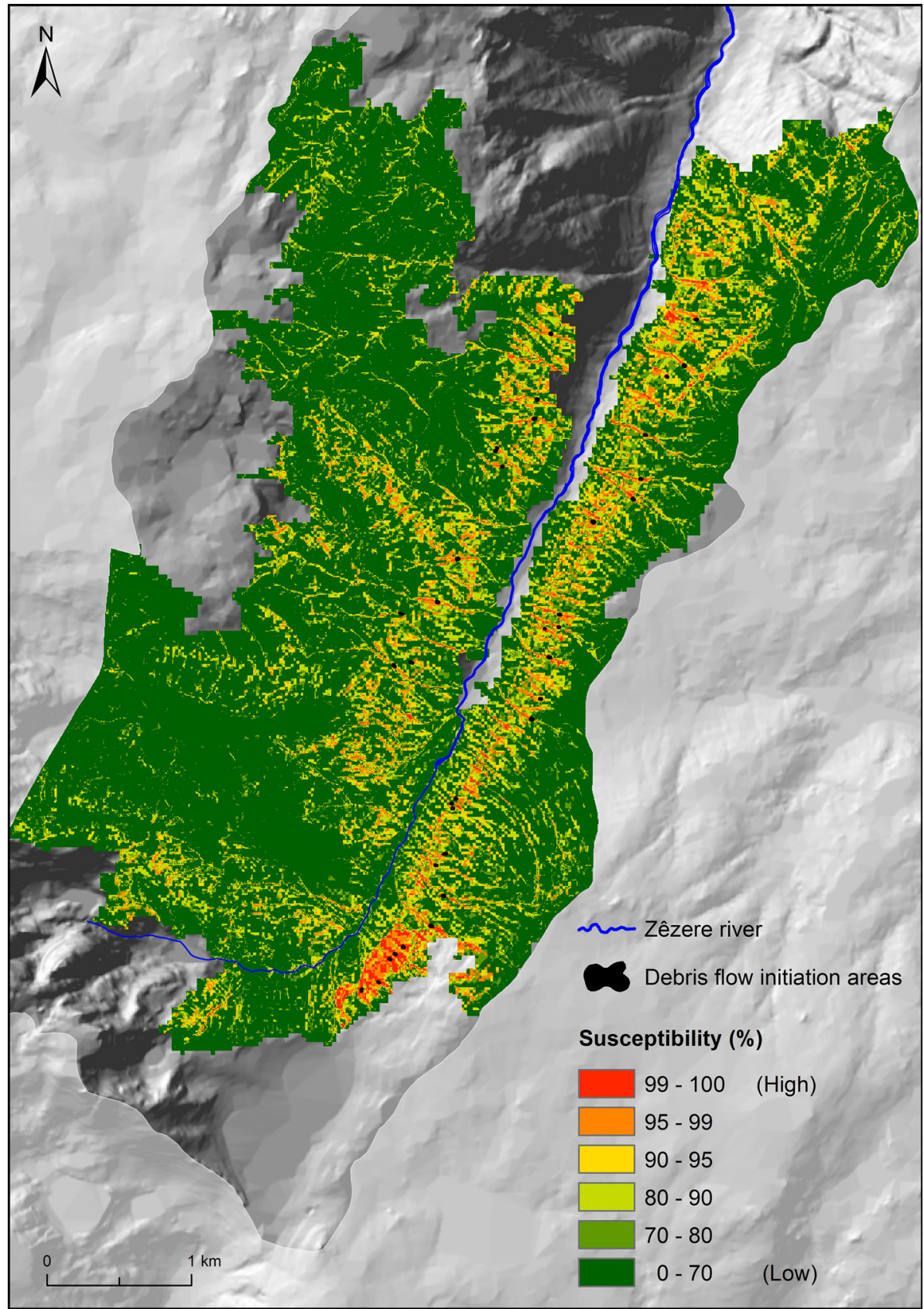

Fig. 7 Susceptibility model for debris flow initiation (mean susceptibility from 3 IV models)

flows modeled with Flow-R and $70.6 \%$ with DI account for over $70 \%$ of the area inside these two classes. The total area classified as susceptible is $1.6 \%$ in Flow-R and $1.7 \%$ in DI (Table 12). 
Table 9 Confusion matrix of the final susceptibility model of debris flow initiation within the burned perimeter, using the IV method

Observed

Debris flow initiation area (1) No debris flow initiation area (0)

Predicted

$\begin{array}{lll}\text { Debris flow initiation area (1) } \quad 136 & 71,465\end{array}$

$\begin{array}{lll}\text { No debris flow initiation area (0) } \quad 12 & 697,292\end{array}$

Table 10 Precision statistics derived from the confusion matrix (IV model)

\begin{tabular}{lll}
\hline Efficiency & $(\mathrm{TP}+\mathrm{TN}) /(\mathrm{TP}+\mathrm{FP}+\mathrm{FN}+\mathrm{TN})$ & 0.91 \\
Misclassification rate & $(\mathrm{FP}+\mathrm{FN}) /(\mathrm{TP}+\mathrm{FP}+\mathrm{FN}+\mathrm{TN})$ & 0.09 \\
Sensitivity & $\mathrm{TP} /(\mathrm{TP}+\mathrm{FN})$ & 0.92 \\
Specificity & $\mathrm{TN} /(\mathrm{FP}+\mathrm{TN})$ & 0.91 \\
False positive rate & $\mathrm{FP} /(\mathrm{FP}+\mathrm{TN})$ & 0.09 \\
False negative rate & $\mathrm{FN} /(\mathrm{TP}+\mathrm{FN})$ & 0.08 \\
\hline
\end{tabular}

Table 11 Percentage of the study area with the highest scores of susceptibility (IV model) versus cumulative percentage of unstable area

\begin{tabular}{llll}
\hline $\begin{array}{l}\text { \% of the study area with the highest } \\
\text { scores of susceptibility }\end{array}$ & $\begin{array}{l}\text { Susceptibility } \\
\text { scores }\end{array}$ & $\begin{array}{l}\text { Cumulative } \\
\text { unstable area }\left(\mathrm{m}^{2}\right)\end{array}$ & $\begin{array}{l}\text { Cumulative \% of } \\
\text { unstable area }\end{array}$ \\
\hline $99-100$ & {$[3.1$ to 8.1$]$} & 1725 & 46.6 \\
$95-99$ & {$[1.5$ to 3.1$]$} & 3025 & 81.7 \\
$90-95$ & {$[0.7$ to 1.5$]$} & 3400 & 91.9 \\
$80-90$ & {$[-0.4$ to 0.7$]$} & 3675 & 99.3 \\
$70-80$ & {$[-1.3$ to } & 3700 & 100 \\
& $-0.4]$ & & 100 \\
$0-70$ & {$[-11.9$ to } & 3700 & \\
\hline
\end{tabular}

\subsection{Susceptibility assessment of debris flow initiation and run-out at the basin scale in a scenario of a recent wildfire}

The selection of the $1 \%$ of the basin area with the highest values of susceptibility resulted in 146 new debris flow initiation areas (with surfaces between 500 and $4275 \mathrm{~m}^{2}$ and an average of $940 \mathrm{~m}^{2}$ ) for the LR model and 179 initiation areas (with surfaces between 500 and $6350 \mathrm{~m}^{2}$ and an average of $1100 \mathrm{~m}^{2}$ ) for the VI model.

Despite the good predictive capability of the LR and IV models, the comparison of the $1 \%$ of the basin area with the highest values of susceptibility showed that only $9.7 \%$ of these areas perfectly overlap. Under this circumstance, we consider that choosing one model over the other just based on the predictive capability may not deliver the most reliable susceptibility map. For this reason, we have decided to merge the debris flow initiation areas given by both methods and use them as input to simulate the run-out at the basin scale with the Flow-R and the DI models. 

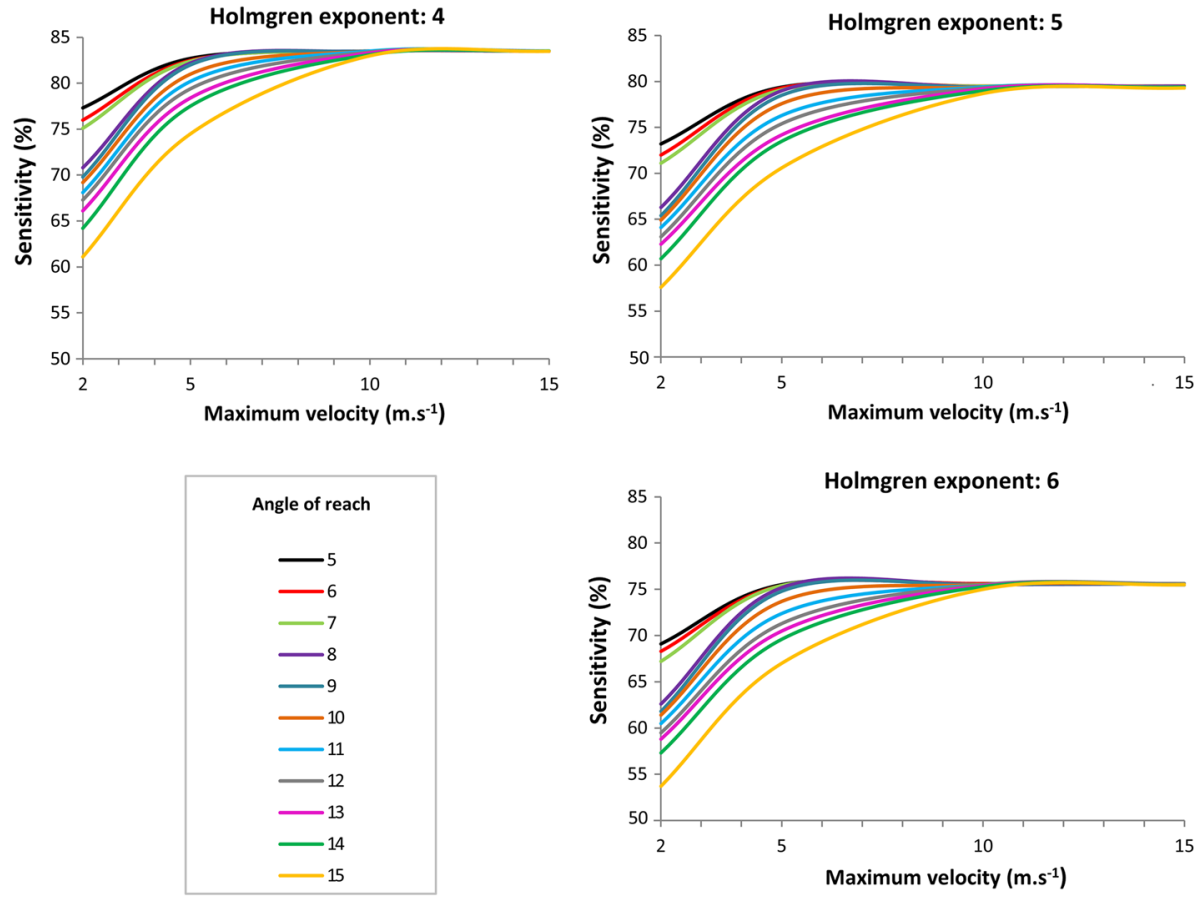

Fig. 8 Sensitive analysis of the calibration parameters (Holmgren exponent, angle of reach and maximum velocity)

Table 12 Run-out simulation of 36 debris flow initiation areas inside the burned area

\begin{tabular}{lllll}
\hline Susceptibility class & \multicolumn{2}{l}{$\%$ of susceptibility class according to the total basin } & Flow-R values & DI values \\
\cline { 2 - 3 } & Flow-R & DI & & \\
\hline Very high & 0.40 & 0.42 & {$[0.11-1]$} & {$[1.42-10.9]$} \\
High & 0.40 & 0.42 & {$[0.032-0.11]$} & {$[0.43-1.42]$} \\
Moderate & 0.40 & 0.42 & {$[0.004-0.032]$} & {$[0.13-0.43]$} \\
Low & 0.40 & 0.42 & {$[0.0003-0.004]$} & {$[0-0.13]$} \\
Total & 1.6 & 1.7 & &
\end{tabular}

Reclassification of Flow-R and DI models into quartiles associated with different levels of susceptibility

The parameters used for the run-out simulation with the Flow-R model were the same that produced the most reliable result during the calibration phase (Sect. 4.2): Holmgren exponent of 4 , angle of reach of $11^{\circ}$ and maximum velocity of $10 \mathrm{~m} \mathrm{~s}^{-1}$.

The Flow-R and DI models were reclassified into quartiles associated with different levels of susceptibility (Table 13). Figures 13 and 14 represent the integration of potential debris flows initiation and run-out areas, using the Flow-R and DI models. The total area classified as susceptible is $9.2 \%$ in Flow-R and $6.6 \%$ in DI (Table 13).

The spatial agreement, i.e., the overlapping between the Flow-R and the DI models, was evaluated using the kappa coefficient (Cohen 1960). When the spatial agreement is 


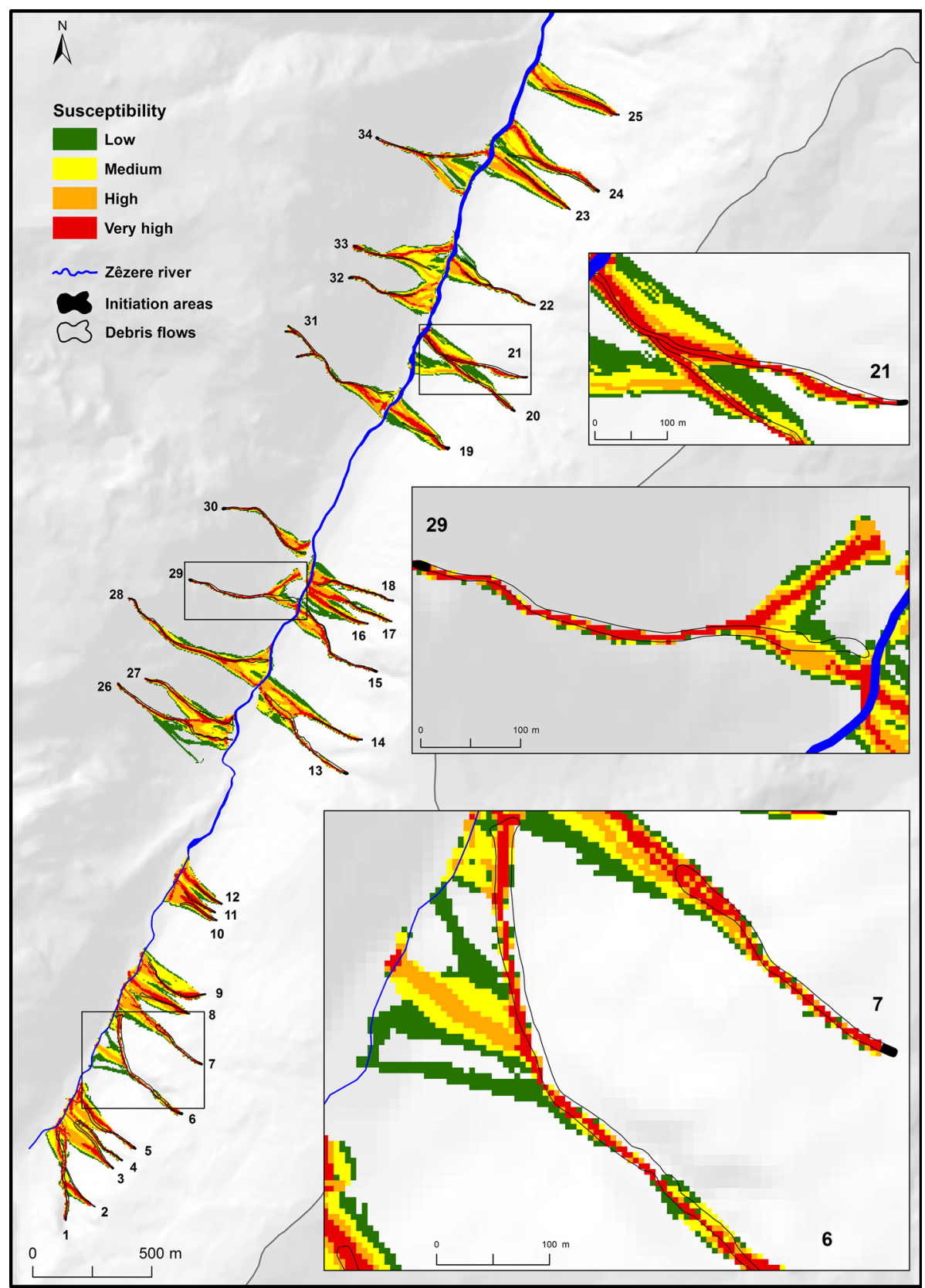

Fig. 9 Run-out simulation for the existing debris flow initiation areas (36), performed with the Flow-R model

established based on a comparison between susceptible and non-susceptible areas, the kappa coefficient obtained (0.50) reveled a moderate agreement between the two models (Landis and Koch 1977). However, when susceptibility levels are considered in the area 


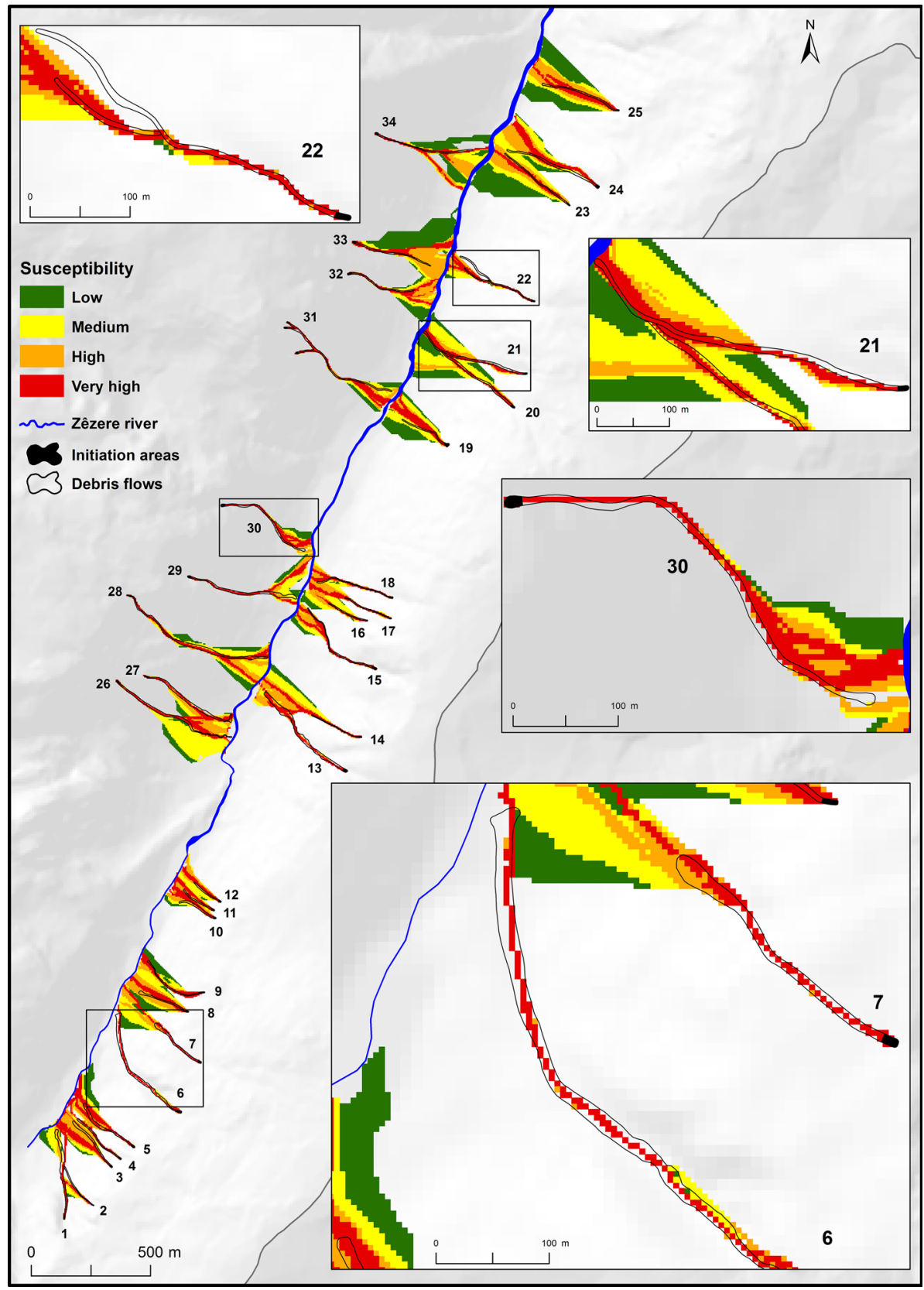

Fig. 10 Run-out simulation for the existing debris flow initiation areas (36), performed with the DI model

classified by the two methods, the agreement decreases. In this case, the kappa coefficient (0.20) indicated only a slight agreement between the models (Landis and Koch 1977) despite the good predictive capability of both. These findings led us to decide for a 


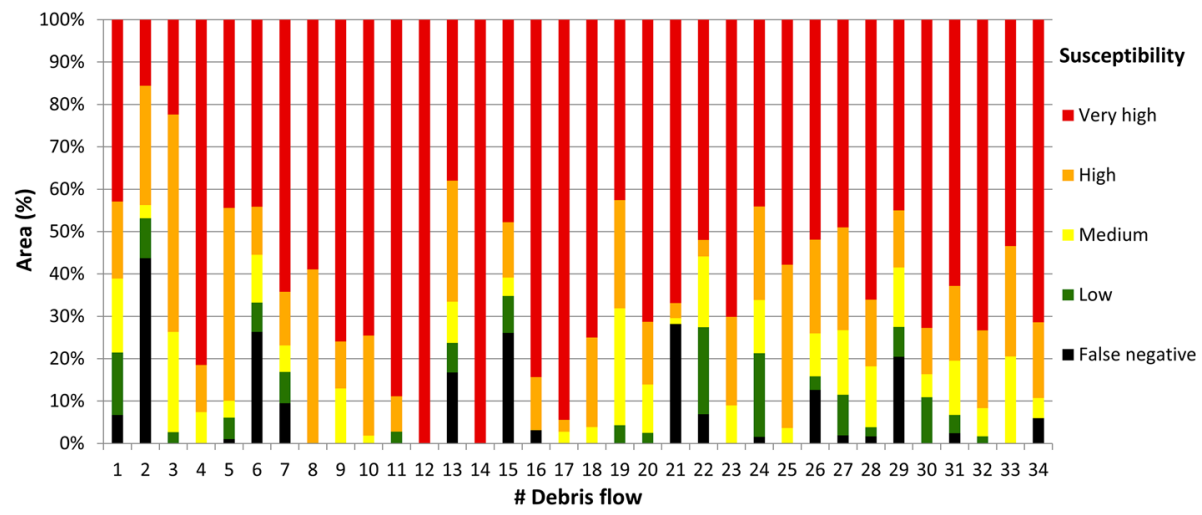

Fig. 11 Percentage of the run-out area (real) captured by each susceptibility class (Flow-R model)

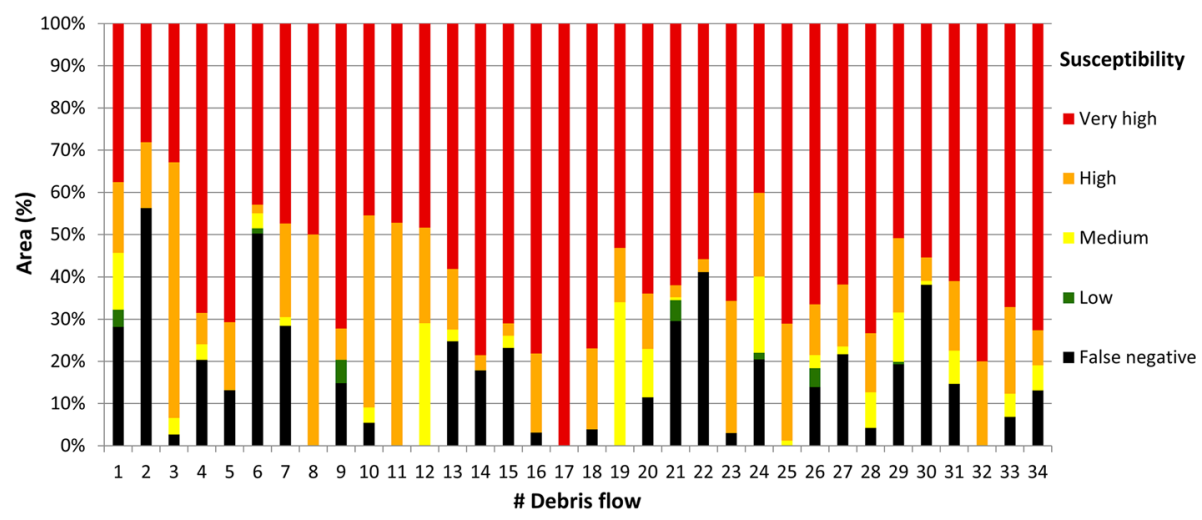

Fig. 12 Percentage of the run-out area (real) captured by each susceptibility class (DI model)

Table 13 Run-out simulation of potential debris flow initiation areas within the total basin

\begin{tabular}{lllll}
\hline Susceptibility class & \multicolumn{2}{l}{$\%$ of susceptibility class according to the total basin } & Flow-R values & DI values \\
\cline { 2 - 3 } & Flow-R & DI & & \\
\hline Very high & 2.3 & 1.64 & {$[0.22-1]$} & {$[26.8-683.0]$} \\
High & 2.3 & 1.64 & {$[0.06-0.22]$} & {$[8.1-26.8]$} \\
Moderate & 2.3 & 1.64 & {$[0.008-0.06]$} & {$[2.69-8.1]$} \\
Low & 2.3 & 1.64 & {$[0.0003-0.008]$} & {$[0-2.69]$} \\
Total & 9.2 & 6.6 & & \\
\hline
\end{tabular}

Reclassification of Flow-R and DI models into quartiles associated with different levels of susceptibility

combination of the Flow-R and DI models outputs in order to construct the final susceptibility map. The combination was performed using the Map Comparison Kit tool (e.g., Visser and Nijs 2006) and is based on a contingency table and the intersection of the 


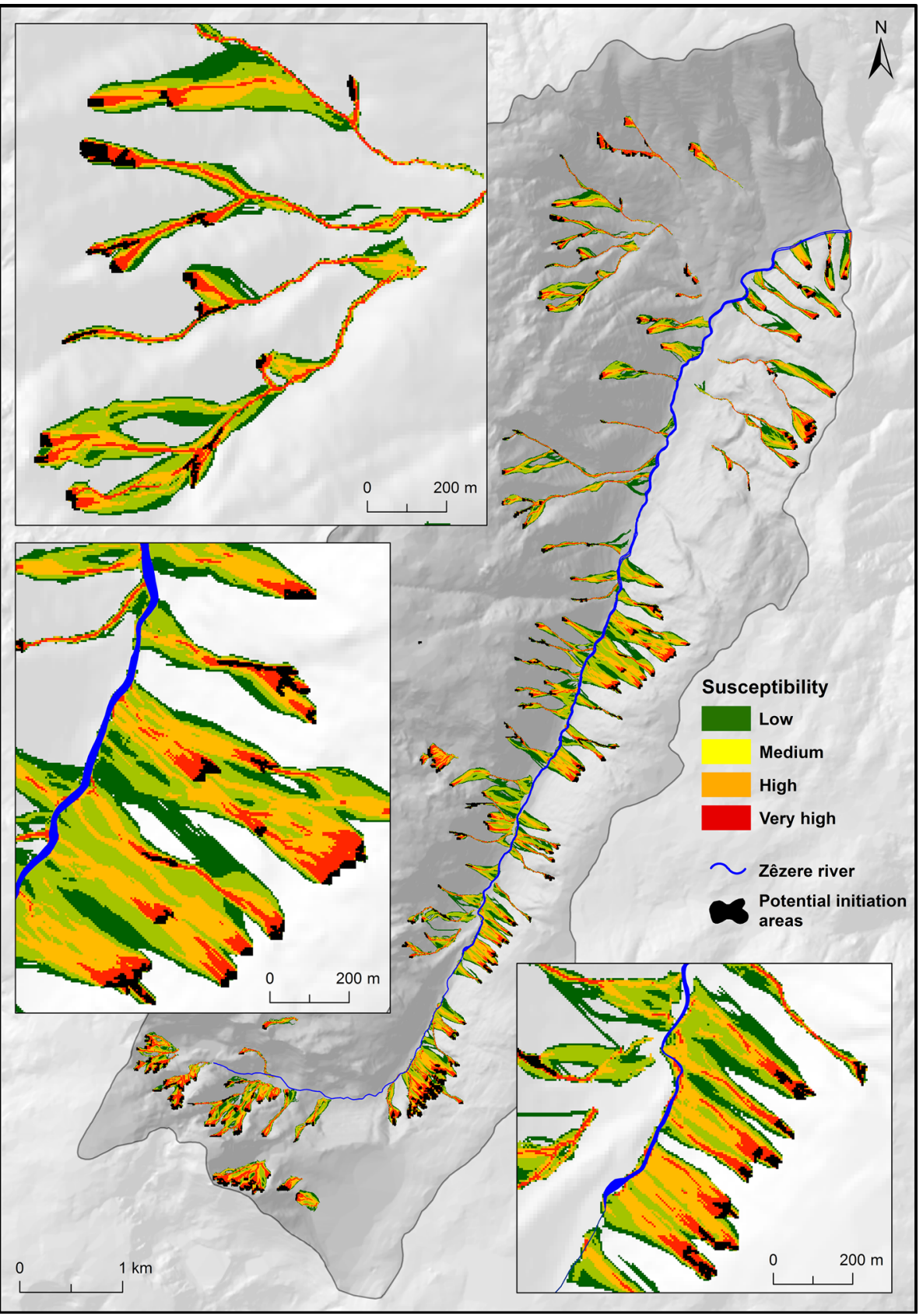

Fig. 13 Integration of potential debris flow initiation and run-out areas using the Flow-R model

susceptibility classes (Table 14). The corresponding final susceptibility map, representing the debris flow initiation and run-out areas at the basin scale in a scenario of a recent wildfire, is shown in Fig. 15. 


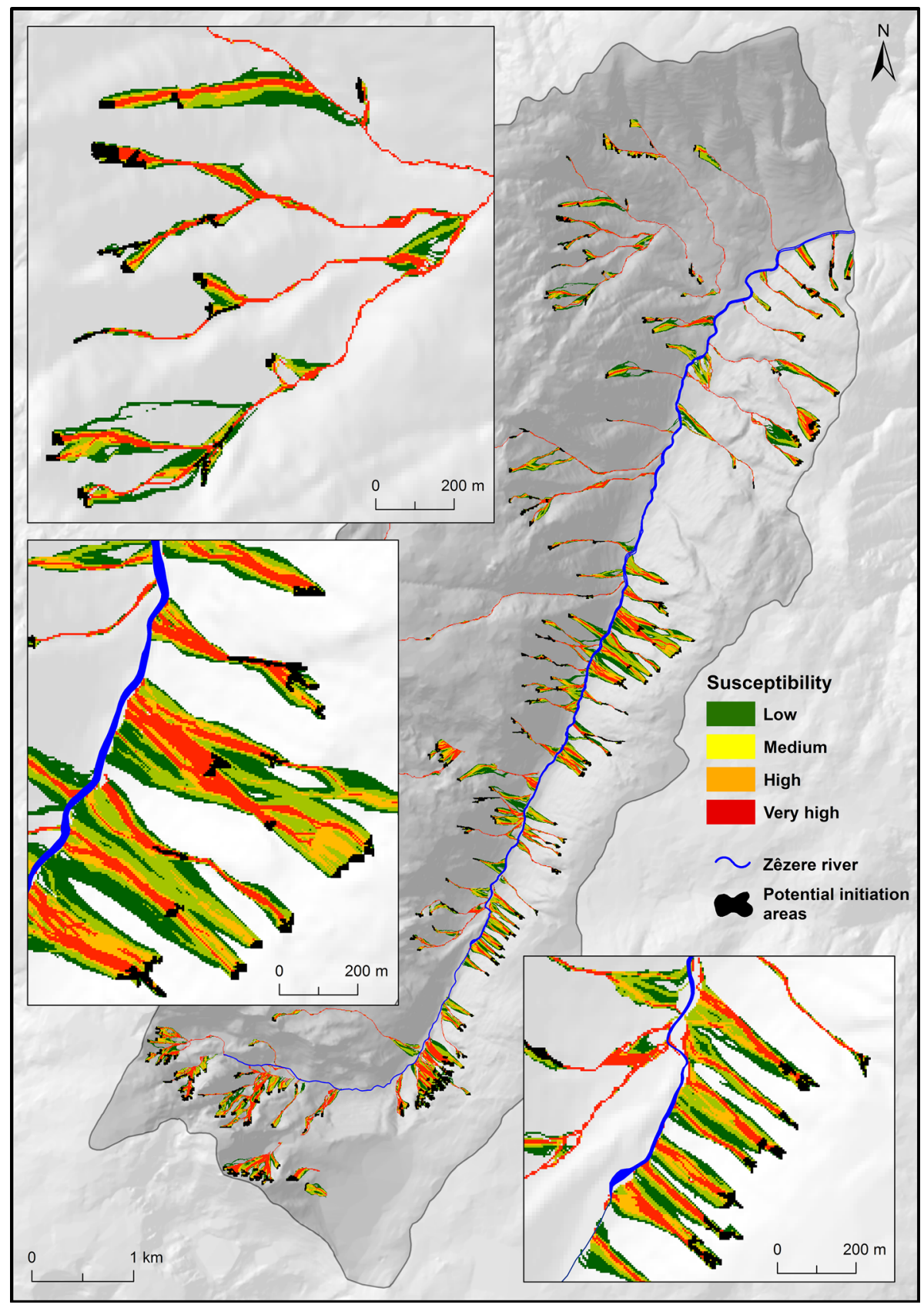

Fig. 14 Integration of potential debris flow initiation and run-out areas using the DI model

The $90 \%$ of the total basin area is classified as not susceptible to debris flow propagation by both models. Moreover, $4.1 \%$ of the total area is classified as susceptible in just one model. In the area classified as susceptible by both models, the perfect agreement occurs in 
Table 14 Contingence table obtained from the overlay of Flow-R and DI models (in \% of the total basin)

\begin{tabular}{lllllll}
\hline Flow-R $\backslash$ Taudem & Null & Low & Moderate & High & Very high & Sum \\
\hline Null & 90.0 & 1.86 & 0.88 & 0.35 & 0.28 & 93.4 \\
Low & 0.15 & 0.30 & 0.71 & 0.36 & 0.13 & 1.6 \\
Moderate & 0.15 & 0.07 & 0.38 & 0.57 & 0.47 & 1.6 \\
High & 0.10 & 0.03 & 0.18 & 0.56 & 0.78 & 1.6 \\
Very high & 0.30 & 0.07 & 0.16 & 0.47 & 0.64 & 1.6 \\
Sum & 90.7 & 2.3 & 2.3 & 2.3 & 2.3 & 100 \\
\hline
\end{tabular}

Colors represent the susceptibility classes of the final map: red very high; orange high; yellow moderate; light green low; dark magenta uncertain, but with potential for high/very high susceptibility; black area classified in just one model

just $1.9 \%$ of the total basin. In addition, it is also possible to infer the areas with highest uncertainty regarding the susceptibility classification. These areas cover $0.6 \%$ of the total basin and are classified as medium/low susceptible by one model and high/very high susceptible by the other model.

\section{Concluding remarks}

In this research, we presented a debris flow susceptibility assessment at the basin scale in a scenario of a recent wildfire, starting from a debris flow event registered in a recently burned area. The susceptibility assessment was separated into two distinct components: initiation and run-out. The mapping was produced by means of low-cost methodologies requiring limited input data. The susceptibility assessment of debris flow initiation was performed using two statistical methods: the LR and the IV. The former involved the computation of 60 models divided in three datasets and the latter the computation of just 3 models. The independent validation of the results defined areas under the curve (AUC) ranging from 0.91 and 0.98 for the LR models and from 0.91 and 0.94 for the IV models. The final LR model resulted from the mean probability of the 60 models, and its robustness was evidenced by the values of sensitivity (95\%) and specificity $(92 \%)$ derived from the confusion matrix. The final IV model resulted from the calculation of the mean scores for the 3 models and presented a sensitivity of $92 \%$ and a specificity of $91 \%$. Plus, the bivariate analysis, supported by the estimation of the accountability and reliability indexes, revealed that the most important predisposing factors to the debris flow initiation in recently burned sub-basins were the slope angle, plan curvature, soil thickness and lithology.

The debris flows run-out assessment was performed using two models: Flow Path Assessment of Gravitational Hazards at a Regional Scale (Flow-R) and D-infinity downslope influence (DI). The data required to implement these models derive almost exclusively from the DEM, allowing their application to extended areas and with limited information. For this same reason, the quality of the DEM is crucial for obtaining reliable results. The models were applied for predicting the run-out from the existing debris flow initiation areas. The validation of the results by visual analysis and statistical parameters of sensitivity (83.5\% in Flow-R and $80.5 \%$ in DI) and false negative rate demonstrated a good performance of both models. 


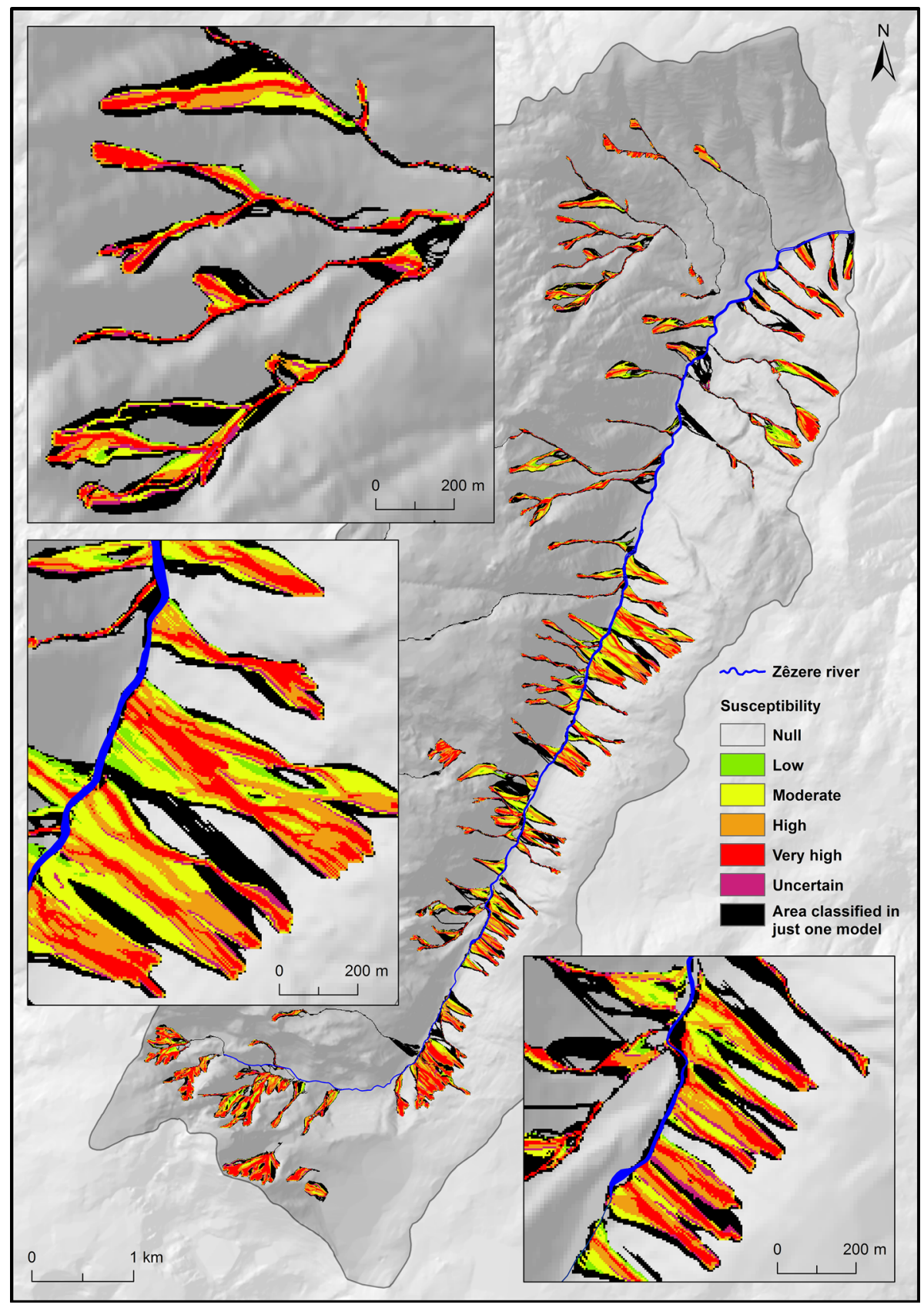

Fig. 15 Debris flow susceptibility assessment at the basin scale in a scenario of a recent wildfire

However, both models have advantages and drawbacks. Concerning the Flow-R, the calibration of the parameters allows to infer the angle of reach and maximum velocity values that best fit the debris flows in the study area. Plus, this model delivered the higher 
true positive rate $(83.5 \%)$ when compared to the spatial pattern of the existing debris flows. On the other hand, the execution and validation of a large number of models can be timeconsuming. The DI has the advantage of being fast and intuitive. The main disadvantage is related to the flow lines generated by the model. These flow lines converge and follow the drainage network, so it is necessary to eliminate them from the moment they reach a principal watercourse. Although this model works well in the study area because the debris flows tend to stop at the bottom of the valley, in other situations it may lead to overestimations of the run-out distance.

Lastly, we observed that the models used for the assessment of debris flow initiation and run-out at the basin scale produced similar results regarding their predictive capability but substantially different results regarding their spatial agreement. For these reasons, we consider that the combination of model outputs is the best approach to obtain the final susceptibility map instead of choosing the one with best predictive capability. Furthermore, the evaluation of the spatial agreement between the two run-out models allowed determining the areas of higher uncertainty in susceptibility classification. These areas need to be addressed more in deep in future detailed investigation in order to determine the real susceptibility level. Until then, it is advisable to address these areas with the same interventions and/or restrictions to be applied to the most susceptible ones, in order to safeguard human lives, structures and infrastructures.

Acknowledgments This work was financed by national funds through FCT-Portuguese Foundation for Science and Technology, I.P., under the framework of the project FORLAND-Hydro-geomorphologic risk in Portugal: driving forces and application for land use planning (PTDC/ATPGEO/1660/2014). Topography data courtesy of the Manteigas Municipality. The authors are thankful to Giacomo D'Amato Avanzi and to an anonymous reviewer for their comments and suggestions that significantly improved the quality of the paper.

\section{References}

Atkinson PM, Massari R (1998) Generalised linear modelling of susceptibility to landsliding in the central Apennines, Italy. Comput Geosci 24:373-385

Avolio MV, Di Gregorio S, Lupiano V, Mazzanti P (2013) SCIDDICA-SS3: a new version of cellular automata model for simulating fast moving landslides. J Supercomput 65:682-696

Ayalew L, Yamagishi H (2005) The application of GIS-based logistic regression for landslide susceptibility mapping in the Kakuda-Yahiko Mountains, Central Japan. Geomorphology 65:15-31

Bai SB, Wang J, Glade T, Bell R (2010a) Comparison on landslide susceptibility assessments before and after the 5.12 WenChuan earthquake at Longnan, China. In: Malet JP, Glade T, Casagli N (eds) Mountain risks: bringing science to society. CERG, Strasbourg, pp 87-93

Bai S, Wang J, Lü G, Zhou P, Hou S, Xu S (2010b) GIS-based logistic regression for landslide susceptibility mapping of the Zhongxian segment in the three Gorges area, China. Geomorphology 115:23-31

Bai S, Lü G, Wang J, Zhou P, Ding L (2011) GIS-based rare events logistic regression for landslidesusceptibility mapping of Lianyungang, China. Environ Earth Sci 62:139-149

Baumann V (2011) Debris flow susceptibility mapping at a regional scale along the National Road N7, Argentina. In: 2011 Pan-Am CGS geotechnical conference

Beguería S (2006) Validation and evaluation of predictive models in hazard assessment and risk management. Nat Hazards 37(3):315-329

Beguería S, Van Asch ThWJ, Malet JP, Gröndahl S (2009) A GIS-based numerical model for simulating the kinematics of mud and debris flows over complex terrain. Nat Hazards Earth Syst Sci 9:1897-1909

Benda LE, Cundy TW (1990) Predicting deposition of debris flows in mountain channels. Can Geotech J 27:409-417

Blahut J, Van Westen CJ, Sterlacchini S (2010a) Analysis of landslide inventories for accurate prediction of debris-flow source areas. Geomorphology 119:36-51 
Blahut J, Horton P, Sterlacchini S, Jaboyedoff M (2010b) Debris flow hazard modelling on medium scale: Valtellina di Tirano, Italy. Nat Hazards Earth Syst Sci 10:2379-2390

Bradley AE (1997) The use of the area under the ROC curve in the evaluation of machine learning algorithms. Pattern Recognit 30(7):1145-1159

Bui DT, Lofman O, Revhaug I, Dick O (2011) Landslide susceptibility analysis in the Hoa Binh province of Vietnam using statistical index and logistic regression. Nat Hazards 59(3):1413-1444

Cannon SH (2001) Debris-flow generation from recently burned watersheds. Environ Eng Geosci 7(4):321-341

Cannon SH, Gartner JE (2005) Wildfire-related debris flow from a hazards perspective. In: Jakob M, Hungr O (eds) Debris-flow hazards and related phenomena. Praxis-Springer, Berlin, pp 363-385

Cannon SH, Reneau SL (2000) Conditions for generation of fire-related debris flows, Capulin Canyon, New Mexico. Earth Surf Process Landf 25:1103-1121

Cannon SH, Powers PS, Savage WZ (1998) Fire-related hyperconcentrated and debris flows on Storm King Mountain, Glenwood Springs, Colorado, USA. Environ Geol 35:210-218

Cannon SH, Bigio ER, Mine E (2001a) A process for fire-related debris flow initiation, Cerro Grande fire, New Mexico. Hydrol Process 15:3011-3023

Cannon SH, Kirkham RM, Parise M (2001b) Wildfire-related debris-flow initiation processes, Storm King Mountain, Colorado. Geomorphology 39:171-188

Cannon SH, Gartner JE, Wilson RC, Bowers JC, Laber JL (2008) Storm rainfall conditions for floods and debris flows from recently burned areas in southwestern Colorado and southern California. Geomorphology 96:250-269

Cannon SH, Gartner JE, Rupert MG, Michael JA, Rea AH, Parrett C (2010) Predicting the probability and volume of postwildfire debris flows in the intermountain western United States. Geol Soc Am Bull 122(1/2):127-144

Cannon SH, Boldt EM, Laber JL, Kean JW, Staley DM (2011) Rainfall intensity-duration thresholds for postfire debris-flow emergency-response planning. Nat Hazards 59:209-236

Carrara A, Cardinali M, Guzzetti F, Reichenbach P (1995) GIS technology in mapping landslide hazard. In: Carrara A, Guzzetti F (eds) Geographical information systems in assessing natural hazards. Kluwer Academic Publisher, Dordrecht, pp 135-175

Carrara A, Crosta GB, Frattini P (2008) Comparing models of debris-flow susceptibility in the alpine environment. Geomorphology 94:353-378

Catani F, Segoni S, Falorni G (2010) An empirical geomorphology-based approach to the spatial prediction of soil thickness at catchment scale. Water Resour Res 46:W05508

Christen M, Kowalski J, Bartelt P (2010) RAMMS: numerical simulation of dense snow avalanches in threedimensional terrain. Cold Reg Sci Technol 63:1-14

Chung CJF, Fabbri A (2003) Validation of spatial prediction models for landslide hazard mapping. Nat Hazards 30(3):451-472

Clerici A, Perego S, Tellini C, Vescovi P (2010) Landslide failure and runout susceptibility in the upper T. Ceno valley (Northern Apennines, Italy). Nat Hazards 52:1-29

Cohen J (1960) A coefficient of agreement for nominal scales. Educ Psychol Meas 20:37-46

Corominas J (1996) The angle of reach as a mobility index for small and large landslides. Can Geotech J $33: 260-271$

Corominas J, Copons R, Vilaplana JM, Altimir J, Amigó J (2003) Integrated landslide susceptibility analysis and hazard assessment in the principality of Andorra. Nat Hazards 30:421-435

Corominas J, Van Westen CJ, Frattini P, Cascini L, Malet JP, Fotopoulou S, Catani F, Van Den Eeckhaut M, Mavrouli O, Agliardi F, Pitilakis K, Winter MG, Pastor M, Ferlisi S, Tofani V, Hervás J, Smith JT (2014) Recommendations for the quantitative analysis of landslide risk. Bull Eng Geol Environ 73:209-263

D'Ambrosio D, Di Gregorio S, Iovine G (2003) Simulating debris flows through a hexagonal cellular automata model: SCIDDICA S3-hex. Nat Hazards Earth Syst Sci 3:545-559

Dahl MPJ, Mortensen LE, Veihe A, Jensen NH (2010) A simple qualitative approach for mapping regional landslide susceptibility in the Faroe Islands. Nat Hazards Earth Syst Sci 10:159-170

Dai FC, Lee CF (2002) Landslide characteristics and slope instability modeling using GIS, Lantau Island, Hong Kong. Geomorphology 42:213-228

Dai FC, Lee CF, Ngai YY (2002) Landslide risk assessment and management: an overview. Eng Geol 64:65-87

Das I, Sahoo S, Van Westen C, Stein A, Hack R (2010) Landslide susceptibility assessment using logistic regression and its comparison with a rock mass classification system, along a road section in the northern Himalayas (India). Geomorphology 114:627-637 
Delmonaco G, Leoni G, Margottini C, Puglisi C, Spizzichino D (2003) Large scale debris-flow hazard assessment: a geotechnical approach and GIS modelling. Nat Hazards Earth Syst Sci 3:443-455

Fannin RJ, Wise MP (2001) An empirical-statistical model for debris flow travel distance. Can Geotech J 38(5):982-994

Fawcett T (2006) An introduction to ROC analysis. Pattern Recognit Lett 27:861-874

Fischer L, Rubensdotter L, Sletten K, Stalsberg K, Melchiorre C, Horton P, Jaboyedoff M (2012) Debris flow modeling for susceptibility mapping at regional to national scale in Norway. In: Eberhardt E et al (eds) Landslides and engineered slopes: protecting society through improved understanding. Taylor \& Francis Group, London, pp 723-729

Frattini P, Crosta G, Carrara A (2010) Techniques for evaluating the performance of landslide susceptibility models. Eng Geol 111:62-72

Fressard M, Maquaire O, Thiery Y (2010) First attempt of landslide susceptibility assessment in the hilly valleys of the Pays d'Auge plateau (Normandy, France). In: Malet JP, Glade T, Casagli N (eds) Mountain risks: bringing science to society. CERG, Strasbourg, pp 95-100

Garcia RAC (2012) Metodologias de avaliação da perigosidade e risco associado a movimentos de vertente: aplicação na bacia do rio Alenquer. PhD dissertation, University of Lisbon (in Portuguese)

Gorsevski PV, Gessler PE, Foltz RB, Elliot WJ (2006) Spatial prediction of landslide hazard using logistic regression and ROC analysis. Trans GIS 10(3):395-415

Greenbaum D, Bowker MR, Dau I, Bropsy H, Greally KB, McDonald AJW, Marsh SH, Northmore KJ, O`Connor EA, Prasad S, Tragheim DG (1995a) Rapid methods for landslide hazard mapping: Fiji case study. Technical report WC/95/28, British Geological Survey (BGS), Natural Environmental Research Council, Keyworth, Nottingham

Greenbaum D, Tutton M, Bowker MR, Browne TJ, Buleka J, Greally KB, Kuna G, McDonald AJW, Marsh SH, O`Connor EA, Tragheim DG (1995b) Rapid methods for landslide hazard mapping: Papua New Guinea case study. Technical report WC/95/27. British Geological Survey (BGS), Natural Environmental Research Council, Keyworth, Nottingham

Greiving S, Van Westen C, Corominas J, Glade T, Malet JP, Van Asch T (2014) Introduction: the componentes of risk governance. In: Van Asch T, Corominas J, Greiving S, Malet JP, Sterlacchini S (eds) Mountain risks: from prediction to management and governance. Advances in natural and technological hazards research. Springer, Dordrecht, pp 1-27

Guillard C, Zêzere JL (2012) Landslide susceptibility assessment and validation in the framework of municipal planning in Portugal: the case of Loures municipality. Environ Manag 50(4):721-735

Guinau M, Vilajosana I, Vilaplana JM (2007) GIS-based debris flow source and runout susceptibility assessment from DEM data: a case study in NW Nicaragua. Nat Hazards Earth Syst Sci 7:703-716

Guzzetti F, Carrara A, Cardinali M, Reichenbach P (1999) Landslide hazard evaluation: a review of current techniques and their application in a multi-scale study, Central Italy. Geomorphology 31:181-216

Guzzetti F, Reichenbach P, Cardinali M, Galli M, Ardizzone F (2006) Estimating the quality of landslide susceptibility models. Geomorphology 81:166-184

Hervás J, Bobrowsky P (2009) Mapping: inventories, susceptibility, hazard and risk. In: Sassa K, Canuti P (eds) Landslides—disaster risk reduction. Springer, Berlin, pp 321-349

Hervás J, Van Den Eeckhaut M, Legorreta G, Trigila A (2013) Landslide inventory and susceptibility and hazard zoning. In: Margottini C, Canuti P, Sassa K (eds) Landslide science and practice, vol 1. Springer, Berlin, pp 1-2

Holmgren P (1994) Multiple flow direction algorithms for runoff modelling in grid based elevation models: an empirical evaluation. Hydrol Process 8:327-334

Horton P, Jaboyedoff M, Bardou E (2008) Debris flow susceptibility mapping at a regional scale. In: Locat J, Perret D, Turmel D, Demers D, Leroueil S (eds) Proceedings of the 4th Canadian conference on Geohazards: from causes to management, Presse de l'Université Laval, Québec, pp 339-406

Horton P, Jaboyedoff M, Zimmermann M, Mazotti B, Longchamp C (2011) Flow-R, a model for debris flow susceptibility mapping at a regional scale-some case studies. In: 5th international conference on debris-flow hazards mitigation: mechanics, prediction and assessment. Ital J Eng Geol Environ Casa Editrice Università La Sapienza, pp 875-884

Horton P, Jaboyedoff M, Rudaz B, Zimmermann M (2013) Flow-R, a model for susceptibility mapping of debris flows and other gravitational hazards at a regional scale. Nat Hazards Earth Syst Sci 13:869-885

Hungr O (1995) A model for the runout analysis of rapid flow slides, debris flows, and avalanches. Can Geotech J 32:610-623

Hungr O, McDougall S (2009) Two numerical models for landslide dynamic analysis. Comput Geosci 35:978-992 
Hungr O, Corominas J, Eberhardt E (2005) State of the art paper \#4, estimating landslide motion mechanism, travel distance and velocity. In: Hungr O, Fell R, Couture R, Eberhardt E (eds) Landslide risk management. Taylor \& Francis, Vancouver, pp 99-128

Hürlimann M, Copons R, Altimir J (2006) Detailed debris flow hazard assessment in Andorra: a multidisciplinary approach. Geomorphology 78:359-372

Hürlimann M, Medina V, Bateman A, Copons R, Altimir J (2007) Comparison of different techniques to analyse the mobility of debris flows during hazard assessment-case study in La Comella catchment, Andorra. In: Chen CL, Major JJ (eds) Debris-flow hazard mitigation: mechanics, prediction and assessment. Millpress, Netherlands, pp 411-422

Hussin HY, Quan Luna B, Van Westen CJ, Christen M, Malet JP, Van Asch ThWJ (2012) Parameterization of a numerical 2-D debris flow model with entrainment: a case study of the Faucon catchment, Southern French Alps. Nat Hazards Earth Syst Sci 12:3075-3090

Iovine G, Di Gregorio S, Lupiano V (2003) Debris-flow susceptibility assessment through cellular automata modeling: an example from 15-16 December 1999 disaster at Cervinara and San Martino Valle Caudina (Campania, southern Italy). Nat Hazards Earth Syst Sci 3:457-468

Jakob M, Hungr O (2005) Introduction: debris flows-a global phenomenon. In: Jakob M, Hungr O (eds) Debris-flow hazards and related phenomena. Praxis-Springer, Berlin, pp 410-443

Jiménez-Valverde A (2012) Insights into the area under the receiver operating characteristic curve (AUC) as a discrimination measure in species distribution modelling. Glob Ecol Biogeogr 21:498-507

Kappes MS, Malet JP, Remaître A, Horton P, Jaboyedoff M, Bell R (2011) Assessment of debris-flow susceptibility at medium-scale in the Barcelonnette Basin, France. Nat Hazards Earth Syst Sci 11:627-641

Kavzoglu T, Sahin EK, Colkesen I (2014) Landslide susceptibility mapping using GIS-based multi-criteria decision analysis, support vector machines, and logistic regression. Landslides 11:425-439

Kritikos T (2013) Geomorphic hazard analyses in tectonically-active mountains: application to the Western Southern Alps, New Zealand. Ph.D. thesis, Department of Geological Sciences, University of Canterbury, New Zealand

Landis JR, Koch GG (1977) The measurement of observer agreement for categorical data. Biometrics 33:159-174

Lari S, Crosta GB, Frattini P, Horton P, Jaboyedoff M (2011) Regional-scale debris flow risk assessment for an alpine valley. In: 5th international conference on debris-flow hazards mitigation: mechanics, prediction and assessment. Ital J Eng Geol Environ, Casa Editrice Università La Sapienza, pp 933-940

Lee S (2007) Comparison of landslide susceptibility maps generated through multiple logistic regression for three test areas in Korea. Earth Surf Process Landf 32:2133-2148

Legros F (2002) The mobility of long-runout landslides. Eng Geol 63:301-331

Mergili M, Schratz K, Ostermann A, Fellin W (2012a) Physically-based modelling of granular flows with open source GIS. Nat Hazards Earth Syst Sci 12:187-200

Mergili M, Fellin W, Moreiras SM, Stötter J (2012b) Simulation of debris flows in the Central Andes based on open source GIS: possibilities, limitations, and parameter sensitivity. Nat Hazards 61:1051-1081

Michoud C, Derron MH, Horton P, Jaboyedoff M, Baillifard FJ, Loye A, Nicolet P, Pedrazzini A, Queyrel A (2012) Rockfall hazard and risk assessments along roads at a regional scale: example in Swiss Alps. Nat Hazards Earth Syst Sci 12:615-629

Migoń P, Vieira G (2014) Granite geomorphology and its geological controls, Serra da Estrela, Portugal. Geomorphology 226:1-14

Montgomery DR, Dietrich WE (1994) A physically-based model for the topographic control on shallow landsliding. Water Resour Res 30:1153-1171

Nefeslioglu HA, Gokceoglu C, Sonmez H (2008) An assessment on the use of logistic regression and artificial neural networks with different sampling strategies for the preparation of landslide susceptibility maps. Eng Geol 97:171-191

O'Brien RM (2007) A caution regarding rules of thumb for variance inflation factors. Qual Quant 41:673-690

O'Brien JS, Julien PY, Fullerton WT (1993) Two dimensional water flood and mudflow simulation. J Hydraul Eng 119:244-261

Oliveira SC (2012) Incidência Espacial e Temporal da Instabilidade Geomorfológica na Bacia do Rio Grande da Pipa (Arruda dos Vinhos). Ph.D. dissertation, University of Lisbon (in Portuguese)

Oliveira SC, Zêzere JL, Catalão J, Nico G (2015) The contribution of PSInSAR interferometry to landslide hazard in weak rock-dominated areas. Landslides 12:703-719

Parise M, Cannon SH (2012) Wildfire impacts on the processes that generate debrisflows in burned watersheds. Nat Hazards 561:217-227 
Perkins NJ, Schisterman EF (2005) The Youden index and the optimal cut-point corrected for measurement error. Biom J 47(4):428-441

Quan Luna B, Blahut J, Van Westen CJ, Sterlacchini S, Van Asch ThWJ, Akbas O (2011) The application of numerical debris flow modelling for the generation of physical vulnerability curves. Nat Hazards Earth Syst Sci 11:2047-2060

Quan Luna B, Remaître A, Van Asch ThWJ, Malet JP, Van Westen CJ (2012) Analysis of debris flow behavior with a one dimensional run-out model incorporating entrainment. Eng Geol 128:63-75

Quan Luna B, Blahut J, Kappes M, Akbas SO, Malet JP, Remaître A, Van Asch T, Jaboyedoff M (2014) Methods for debris flow hazard and risk assessment. In: Van Asch T, Corominas J, Greiving S, Malet JP, Sterlacchini S (eds) Mountain risks: from prediction to management and governance. Advances in natural and technological hazards research. Springer, Dordrecht, pp 133-177

Quan Luna B, Blahut J, Van Asch T, Van Westen CJ, Kappes M (2016) ASCHFLOW_a dynamic landslide run-out model for medium scale hazard analysis. Geoenviron Disasters 3:29. doi:10.1186/s40677-0160064-7

Ray RL, De Smedt F (2009) Slope stability analysis on a regional scale using GIS: a case study from Dhading, Nepal. Environ Geol 57:1603-1611

Remaître A, Malet JP, Maquaire O, Ancey C, Locat J (2005) Flow behavior and runout modelling of a complex debris flow in a clay-shale basin. Earth Surf Process Landf 30:479-488

Rickenmann D (1999) Empirical relationships for debris flows. Nat Hazards 19:47-77

Rickenmann D, Zimmermann M (1993) The 1987 debris flows in the Switzerland: documentation and analysis. Geomorphology 8:175-189

Riley KL (2013) Statistical modeling of rare stochastic disturbance events at continental and global scales: post-fire debris flows and wildland fires. Theses, Dissertations, Professional Papers. Paper 1401

Scheidl C, Rickenmann D (2010) Empirical prediction of debris-flow mobility and deposition on fans. Earth Surf Process Landf 35:157-173

Schicker R, Moon V (2012) Comparison of bivariate and multivariate statistical approaches in landslide susceptibility mapping at a regional scale. Geomorphology 161-162:40-57

Segoni S, Rossi G, Catani F (2012) Improving basin scale shallow landslide modelling using reliable soil thickness maps. Nat Hazards 61:85-101

Soeters R, Van Westen CJ (1996) Slope instability recognition, analysis and zonation. In: Turner AK, Schuster RL (eds) Landslide: investigation and mitigation. Special report, vol 247. Transportation Research Board, National Research Council, National Academy Press, Washington, pp 129-177

Staley DM, Kean JW, Cannon SH, Schmidt KM, Laber JL (2013) Objective definition of rainfall intensityduration thresholds for the initiation of post-fire debris flows in southern California. Landslides 10:547-562

Staley DM, Wasklewicz TA, Kean JW (2014) Characterizing the primary material sources and dominant erosional processes for post-fire debris-flow initiation in a headwater basin using multi-temporal terrestrial laser scanning data. Geomorphology 214:324-338

Stalsberg K, Fischer L, Rubensdotter L, Sletten K (2012) Approaches to shallow landslide and debris flowassessments in Norway. In: Eberhardt E et al (eds) Landslides and engineered slopes: protecting society through improved understanding. Taylor \& Francis Group, London, pp 737-740

Süzen ML, Doyuran V (2004) A comparison of the GIS based landslide susceptibility assessment methods: multivariate versus bivariate. Environ Geol 45:665-679

Tarboton DG (1997) A new method for the determination of flow directions and upslope areas in grid digital elevation models. Water Resour Res 33:309-319

Tarboton DG (2003) Terrain analysis using digital elevation models in hydrology. In: 23rd ESRI international users conference, San Diego, California, July 7-11

Tarboton DG, Baker ME (2008) Towards an algebra for terrain-based flow analysis. In: Mount NJ, Harvey GL, Aplin P, Priestnall G (eds) Representing, modeling and visualizing the natural environment: innovations in GIS 13. CRC Press, Florida, pp 167-194

Van Asch ThWJ, Tang C, Alkema D, Zhu J, Zhou W (2014) An integrated model to assess critical rainfall thresholds for run-out distances of debris flows. Nat Hazards 70:299-311

Van den Eeckhaut M, Vanwalleghem T, Poesen J, Govers G, Verstraeten G, Vandekerckhove L (2006) Prediction of landslide susceptibility using rare events logistic regression: a case-study in the Flemish Ardennes (Belgium). Geomorphology 76:392-410

Van den Eeckhaut M, Reichenbach P, Guzzetti F, Rossi M, Poesen J (2009) Combined landslide inventory and susceptibility assessment based on different mapping units: an example from the Flemish Ardennes, Belgium. Nat Hazards Earth Syst Sci 9:507-521

Van den Eeckhaut M, Hervás J, Jaedicke C, Malet JP, Picarelli L (2010) Calibration of logistic regression coefficients from limited landslide inventory data for European-wide landslide susceptibility 
modelling. In: Malet JP, Glade T, Casagli N (eds) Mountain risks: bringing science to society. CERG, Strasbourg, pp 515-521

Van Westen CJ, Terlien TJ (1996) An approach towards deterministic landslide hazard analysis in GIS: a case study from Manizales (Colombia). Earth Surf Process Landf 21:853-868

Van Westen CJ, Van Asch TWJ, Soeters R (2006) Landslide hazard and risk zonation-why is it still so difficult? Bull Eng Geol Environ 65:167-184

Van Westen CJ, Castellanos E, Kuriakose SL (2008) Spatial data for landslide susceptibility, hazard, and vulnerability assessment: an overview. Eng Geol 102:112-131

Van Westen CJ, Ghosh S, Jaiswal P, Martha TR, Kuriakose SL (2013) From landslide inventories to landslide risk assessment; an attempt to support methodological development in India. In: Margottini C, Canuti P, Sassa K (eds) Landslide science and practice, vol 1. Springer, Berlin, pp 3-20

Van Westen CJ, Kappes M, Quan Luna B, Frigerio S, Glade T, Malet JP (2014) Medium-scale multi-hazard risk assessment of gravitational processes. In: Van Asch T, Corominas J, Greiving S, Malet JP, Sterlacchini S (eds) Mountain risks: from prediction to management and governance. Advances in Natural and Technological Hazards Research. Springer, Dordrecht, pp 201-231

Vergari F, Della Seta M, Del Monte M, Fredi P, Palmieri L (2011) Landslide susceptibility assessment in the Upper Orcia Valley (Southern Tuscany, Italy) through conditional analysis: a contribution to the unbiased selection of causal factors. Nat Hazards Earth Syst Sci 11:1475-1497

Vieira G, Mora C, Gouveia MM (2004) Oblique rainfall and contemporary geomorphological dynamics (Serra da Estrela, Portugal). Hydrol Process 18:807-824

Visser H, Nijs T (2006) The map comparison 5 kit. Environ Model Softw 21:346-358

Wohl EE, Pearthree PP (1991) Debris flows as geomorphic agents in the Huachuca Mountains of southeastern Arizona. Geomorphology 4:273-292

Yin KL, Yan TZ (1988) Statistical prediction model for slope instability of metamorphosed rocks. In: Bonnard C (ed) Proceedings of the fifth international symposium in landslides, Lausanne, Balkema, Rotterdam, pp 1269-1272

Zêzere JL (2002) Landslide susceptibility assessment considering landslide typology. A case study in the area north of Lisbon (Portugal). Nat Hazards Earth Syst Sci 2:73-82

Zêzere JL, Reis E, Garcia R, Oliveira S, Rodrigues ML, Vieira G, Ferreira AB (2004) Integration of spatial and temporal data for the definition of different landslide hazard scenarios in the area north of Lisbon (Portugal). Nat Hazards Earth Syst Sci 4(1):133-146 